\title{
An integrated approach to assessing multiple stressors for coastal Lake Superior
}

\author{
Gerald J. Niemi, ${ }^{1, *}$ Euan D. Reavie, ${ }^{2}$ Gregory S. Peterson, ${ }^{3}$ John R. Kelly, ${ }^{3}$ \\ Carol A. Johnston, ${ }^{4}$ Lucinda B. Johnson, ${ }^{1}$ Robert W. Howe, ${ }^{5}$ George E. \\ Host, ${ }^{1}$ Tom P. Hollenhorst, ${ }^{1,3}$ Nicholas P. Danz, ${ }^{6}$ Jan J. H. Ciborowski, ${ }^{7}$ \\ Terry N. Brown, ${ }^{1}$ Valerie J. Brady, ${ }^{1}$ and Richard P. Axler ${ }^{1}$ \\ ${ }^{1}$ Center for Water and the Environment, Natural Resources Research Institute, University of Minnesota Duluth, \\ 5013 Miller Trunk Highway, Duluth, Minnesota 55811-1442, USA \\ ${ }^{2}$ Ely Field Station, Center for Water and the Environment, Natural Resources Research Institute, University of \\ Minnesota Duluth, 1900 East Camp Street, Ely, Minnesota 55731, USA \\ ${ }^{3}$ Environmental Protection Agency, Office of Research and Development, National Health and Environmental Effects \\ Research Laboratory, Mid-Continent Ecology Division, 6201 Congdon Boulevard Duluth, Minnesota 55804-2595, \\ USA \\ ${ }^{4}$ Department of Biology and Microbiology, \\ South Dakota State University, Box 2207B Brookings, South Dakota 57007-0869, USA \\ ${ }^{5}$ Department of Natural and Applied Sciences, Cofrin Center for Biodiversity University of Wisconsin-Green Bay, \\ Green Bay, Wisconsin 54311-7001, USA \\ ${ }^{6}$ Department of Natural Sciences, University of Wisconsin-Superior, 132 McCaskill Hall, Superior, Wisconsin 54880, \\ USA \\ ${ }^{7}$ Department of Biological Sciences, University of Windsor, Windsor, Ontario N9B 3P4, Canada \\ *Corresponding author: gniemi@d.umn.edu
}

Biological indicators can be used both to estimate ecological condition and to suggest plausible causes of ecosystem degradation across the U.S. Great Lakes coastal region. Here we use data on breeding bird, diatom, fish, invertebrate, and wetland plant communities to develop robust indicators of ecological condition of the U.S. Lake Superior coastal zone. Sites were selected as part of a larger, stratified random design for the entire U.S. Great Lakes coastal region, covering gradients of anthropogenic stress defined by over 200 stressor variables (e.g. agriculture, altered land cover, human populations, and point source pollution). A total of 89 locations in Lake Superior were sampled between 2001 and 2004 including 31 sites for stable isotope analysis of benthic macroinvertebrates, 62 sites for birds, 35 for diatoms, 32 for fish and macroinvertebrates, and 26 for wetland vegetation. A relationship between watershed disturbance metrics and ${ }^{15} \mathrm{~N}$ levels in coastal macroinvertebrates confirmed that watershed-based stressor gradients are expressed across Lake Superior's coastal ecosystems, increasing confidence in ascribing causes of biological responses to some landscape activities. Several landscape metrics in particular-agriculture, urbanization, human population density, and road density-strongly influenced the responses of indicator species assemblages. Conditions were generally good in Lake Superior, but in some areas watershed stressors produced degraded conditions that were similar to those in the southern and eastern U.S. Great

Aquatic Ecosystem Health \& Management, 14(4):356-375, 2011. Copyright (C) 2011 AEHMS. ISSN: 1463-4988 print/ 1539-4077 online DOI: $10.1080 / 14634988.2011 .628254$ 
Lakes. The following indicators were developed based on biotic responses to stress in Lake Superior in the context of all the Great Lakes: (1) an index of ecological condition for breeding bird communities, (2) diatom-based nutrient and solids indicators, (3) fish and macroinvertebrate indicators for coastal wetlands, and (4) a non-metric multidimensional scaling for wetland plants corresponding to a cumulative stress index. These biotic measures serve as useful indicators of the ecological condition of the Lake Superior coast; collectively, they provide a baseline assessment of selected biological conditions for the U.S. Lake Superior coastal region and prescribe a means to detect change over time.

Keywords: birds, diatoms, fish, indicators, macroinvertebrates, plants

\section{Introduction}

Substantial need exists to identify and validate environmental indicators for assessing, and ideally diagnosing, causes for changes in aquatic resources over time (Niemi and McDonald, 2004; Niemi et al., 2004). During the past ten years, several comprehensive research projects have increased our understanding of Great Lakes coastal ecosystems and tested the performance of many environmental indicators for the Great Lakes coastal region (Mackey and Goforth, 2005; Lawson, 2004; Niemi et al., 2007; Burton et al., 2008). In 2001, we initiated the Great Lakes Environmental Indicators (GLEI) project for selected biological communities across the entire U.S. Great Lakes coastal region to formulate multi-species biotic indicators of ecological conditions and potentially to diagnose causes of degradation of these conditions (Niemi et al., 2007). Results from our investigations supplement and complement on-going reporting on the condition of the Great Lakes ecosystem, including the coastal regions (Schierow and Chesters, 1988; Steinhart et al., 1982; Bertram and Stadler-Salt, 1998; Bertram et al., 2003; Environment Canada and U.S. EPA, 2005; Seilheimer and Chow Fraser, 2006; Burton et al., 2008; Dobiesz et al., 2010).

Here we report selected results from the GLEI project for the U.S. portion of the Lake Superior coastal region. This summary is complementary to Niemi et al. (2009), which summarized ecological indicator analyses in Lake Huron. A major incentive for this lake-specific approach to indicator development resulted from earlier studies by Brazner et al. (2007a) and Hanowski et al. (2007a). They clearly showed that indicator development was highly influenced by the lake on which data were gathered; hence, lake is an important classification factor in the robust identification of environmental indicators. Specific objectives included: (1) a summarization of data gathered on breeding birds, diatoms, fish, macroinvertebrates, and wetland vegetation for the U.S. portion of Lake Superior, (2) linkage and responses of these biota with potential stressors, (3) identification of gradients of stress within the U.S. Lake Superior coastal region, and (4) a brief synthesis on the similarities among these taxa with respect to Lake Superior. Data have previously been presented and summarized for the entire U.S. Great Lakes coastal region (Niemi et al., 2006, 2007; http://glei.nrri.umn.edu).

\section{Methods}

Study sites were selected across gradients of anthropogenic stress using a stratified random design as part of the larger sampling strategy for the entire U.S. Great Lakes coastal region (Danz et al., 2005); 153 sites in coastal wetlands, uplands, estuaries/bays, and high-energy shoreline were selected in the Lake Superior basin (Figure 1). Coastal wetlands were classified as open coastal, riverine, or barrierbeach protected, based on Keough et al. (1999). Site selection was based on quantifying the land-based stress in a geographic information system (GIS) for 762 coastal segment-sheds that encompassed the entire U.S. basin (Hollenhorst et al., 2007; Johnston et al., 2009a). Sampled sites were represented within the GIS by polygons encompassing the sampling points at a selected locale as described for Lake Huron by Niemi et al. (2009).

The status of Lake Superior's coastal ecosystem relative to the more than 200 environmental variables gathered from GIS data sets across the entire U.S. Great Lakes basin was represented by seven categories of environmental variation (Danz et al., 2005). Principal components analysis (PCA) was used within each category of environmental variation to reduce dimensionality and derive overall gradients (Danz et al., 2007; Niemi et al., 2007). These gradients included agriculture, atmospheric 


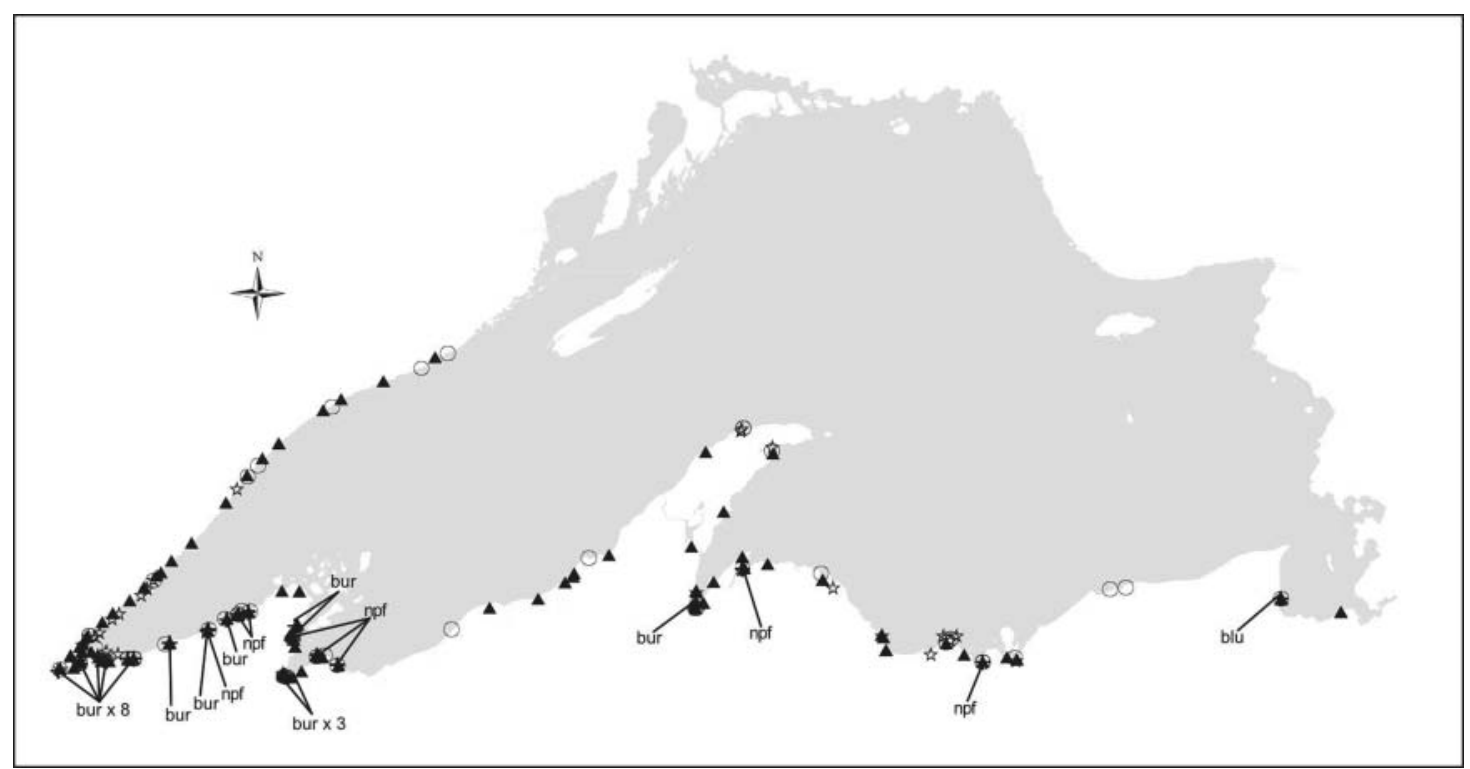

Figure 1. Location of study sites for breeding birds, diatoms, fish and invertebrates, and wetland vegetation in Lake Superior (triangles $=$ birds, stars $=$ diatoms, circles $=$ fish and invertebrates, and plus sign $=$ wetland vegetation; blu $=$ bluejoint $/$ tussock sedge plant community, bur $=$ burreed/lake sedge plant community, $\mathrm{npf}=$ northern poor fen plant community).

deposition, human population and development, land cover, point source pollution, soils, and a cumulative stress index (CSI) which represented a combination of five of the six gradients, excluding soils. The data used in these analyses were primarily landscape data; the only data available for all five Great Lakes. Because Lake Superior lies exclusively in the Laurentian Mixed Forest province (212), only data from that province as per Danz et al. (2005) were used here. Relationships of the biological assemblages to these gradients are described and are specific to their respective sections below. Note that the gradients used for respective biological assemblages varied slightly depending on which gradients were most useful in explaining variation for the respective taxa. The original literature for the development of indicators for these taxa may need to be reviewed to fully comprehend these gradients (Niemi et al., 2006, 2007).

\section{Stable isotopes}

Stable isotopes of nitrogen $\left(\delta^{15} \mathrm{~N}\right)$ have been used to identify anthropogenic contributions in nitrogen loading to aquatic ecosystems, thereby establishing linkages between landscape and coastal waters (e.g. McClelland and Valiela, 1998). The $\delta^{15} \mathrm{~N}$ measured in biological tissues can be an "exposure" indicator to reflect the relative contributions of different $\mathrm{N}$ sources and biogeochemical processing, and in the case of the Great Lakes, higher values have been associated with greater levels of anthropogenic disturbance in watersheds (Peterson et al., 2007). The $\delta^{15} \mathrm{~N}$ values of biota from sites across Lake Superior were regressed against the agriculture $(\mathrm{AC} 1)$ principal component (PC) of Danz et al. (2005); a previous basinwide study had revealed the strongest relationship with this $\mathrm{AC} 1$ disturbance metric (Peterson et al., 2007). Benthic macroinvertebrates were collected for stable isotope analysis at 31 Lake Superior sites between 2001 and 2004; the original ten embayment and nearshore sites in Lake Superior included in Peterson et al. (2007) were supplemented with 21 additional sites, all within a depth range of $0-15 \mathrm{~m}$, but including coastal wetlands, embayments, and nearshore habitats. Similar taxa were collected using Ponar grabs at 12 embayment and seven nearshore sites, and using sweep nets in submerged aquatic vegetation at 12 wetland sites. The sites within each habitat class spanned a similar AC1 range, and most of the available AC1 gradient, for Lake Superior. Nitrogen stable isotope ratios in macroinvertebrates were measured using mass spectrometry and are expressed as $\delta^{15} \mathrm{~N}$ values, with units of parts-per-thousand (details in Peterson et al., 2007). 


\section{Birds}

Birds were sampled at 321 points (62 in Lake Superior) in 215 wetland polygons (45 in Lake Superior) using a standard protocol (Ribic et al., 1999; Hanowski et al., 2007a). Although the wetlands themselves were selected according to the stratified random method described by Danz et al. (2005), bird samples for each wetland (one to five points depending on wetland area) were located along roads, trails, shorelines, or other accessible points where wetland habitat extended at least 100 metres in three directions. All birds seen or heard during a 15 min sample period were recorded within a 100 metre radius half-circle extending from the point into the wetland. Wetlands within the half-circle were non-forested and dominated by a variety of vegetation types ranging from rushes to shrubs (e.g. Alnus rugosa). All but eight half-circle sample areas were surrounded by at least ten percent emergent herbaceous vegetation.

A reference gradient of environmental condition (Howe et al., 2007a, 2007b) was derived by PCA of 39 variables describing land use (e.g. proportion of cultivated land within 100 metres, 500 metres, one kilometre, and five kilometres of wetland center), wetland attributes (e.g. proportion wetland area within 100 metres, 500 metres, one kilometre, and five kilometres), and eight PC scores from Danz et al. (2005) (e.g. agricultural stress gradient PC1, atmospheric deposition stress gradient PC1). The PCA of all 39 environmental variables yielded five interpretable axes of variation, accounting for 68 percent of the overall variance. Principal component $1(24.3 \%$ of the variation) was correlated (negatively) with proportion of natural vegetation within 500 metres of the wetland complex centroid and related landscape variables. PC 2, accounting for $17.4 \%$ of the overall variation, was strongly correlated with proportion of cultivated land (all scales) and a multivariate index (principal component) of agricultural activity defined by Danz et al. (2007). PC 3, accounting for $13.3 \%$ of the variation, separated sites with extensive wetland area in the surrounding landscape from sites with predominately upland vegetation or non-wetland land uses such as residential and cultivated lands. PC 4 (7.4\% of the variation) was negatively correlated with industrial land cover types and positively correlated with residential land use. Finally, PC 5 (5.7\% of the variation) was negatively correlated with the proportion of natural vegetation of any type within 250 metres of the wetland and positively correlated with road length within 500 metres. Scores from these five PCs accounted for 68 percent of the overall variation. We changed the direction of the PC scores (multiplying by -1 , for example) so that each axis formed a gradient of environmental condition ranging from highest (condition $=0$ ) to lowest (condition $=10$ ) level of anthropogenic impact. The scores were then combined into a single value of environmental condition by weighting each PC score by the percent variation associated with the axis. Results were scaled again to form a reference gradient ranging from zero (poorest environmental condition or highest anthropogenic stress) to ten (best condition or lowest anthropogenic stress).

Bird sample points were assigned to categories based on the wetland environmental condition (zero to ten). For each category, we then plotted the proportion of points at which a given bird species was observed (Howe et al., 2007b). This plot defined a four parameter logistic function (Howe et al., 2007a) reflecting the response of the species to anthropogenic stress. The best-fit logistic function was estimated iteratively by the Solver algorithm in Microsoft Excel, using the following goodnessof-fit criteria: $(\mathrm{O}-\mathrm{E})^{2} /[\mathrm{E}(1-\mathrm{E})]$, where $\mathrm{O}=$ the observed probability or proportion of occurrence of a species among field samples and $\mathrm{E}$ is the expected proportion of occurrence given a set of four parameters of the logistic function. The computer algorithm essentially applies a trial and error analysis of parameter values until it finds the logistic function that best fits the observed data (Hilborn and Mangel, 1997). Birds that are intolerant of human disturbance, for example, will show a response function that increases in probability as the environmental reference gradient increases from 0 to 10. The shape of the curve (gradual increase vs. Sshaped increase) and the difference between lowest and highest probabilities of occurrence are dictated by the parameters of the logistic function. Based on these functions, a bird community indicator, or index of ecological condition (IEC), was calculated for specific wetlands using the probability method of Howe et al. (2007a). This method uses an iterative computer algorithm to find the value of IEC that simultaneously best fits the observed probabilities of occurrence of selected bird species. For example, if highly sensitive bird species were always present at a site (probability $=1$ ) and highly tolerant species were always absent (probability $=0$ ), then the most likely IEC of the site would approach 10 . 
We limited our analysis to 23 species (Howe et al., 2007b) that ranged across the Great Lakes region and showed the strongest responses, either positive or negative, to the anthropogenic stress gradient. We used Games-Howell post-hoc test for all pairwise comparisons between bird-based IECs from Lake Superior wetlands and wetlands from other lakes.

\section{Diatoms}

At each coastal locale we aimed to collect diatom assemblages from surface sediments, although other substrates (rocks, macrophytes, snags) were substituted as necessary if sediments were not available. Sampling and processing methods are described in detail by Reavie et al. (2006). Briefly, remains of diatoms were isolated from the organic sample matrix by digestion with reagents, cleaned with deionized water, and plated on microscope slides. Diatom assemblages were assessed by identifying taxa and identifying at least 400 valves along transects.

Water quality measurements, including nutrients, ions, and physicochemical parameters, were simultaneously collected at each location in order to calibrate the environmental characteristics of the diatom taxa (Reavie et al., 2006). Using weighted averaging (WA) regression and calibration several diatom-based transfer functions were derived from the assemblages and corresponding water quality data (Battarbee et al., 2001). The 352 common diatom species were calibrated to several water quality variables; total phosphorus (TP) and total suspended solids (TSS) concentrations were identified as two of the most important variables in terms of strong diatom-environmental relationships and value for aquatic management. Using TP as an example, species optima and tolerances for TP were calculated by relating diatom species assemblages to chemical measurements. These coefficients comprised the TP transfer function, i.e. the diatom indicator for nutrient status. The model was then applied to all samples by taking the TP optimum of each taxon, weighting it by its percent abundance in each sample, and calculating the average of the combined weighted optima of all taxa in the sample (Battarbee et al., 2001) to provide diatominferred (DI) TP. Measured TP was compared to DI TP to estimate the power of the model to track nutrients.
To illustrate the relationships between diatombased inferences and select anthropogenic stressor variables, DI TP was then regressed against anthropogenic (e.g. agriculture and human population development) and natural (e.g. soil characteristics) watershed properties (i.e. scores derived from PCAs of watershed data) using multiple linear regression to identify the ability of diatom assemblages to reflect watershed stressors. This DI-stressor relationship was compared with the whole set of Great Lakes diatom sample locations (Reavie et al., 2006) and the Lake Superior coastline (35 sites, 20 with detailed watershed stressor data).

\section{Fish and invertebrates}

Fish and macroinvertebrates were sampled in 2002 and 2003 from 32 Lake Superior coastal sites, including 15 from wetlands, 13 from high energy sites, and four from embayments. Fish were collected using fyke nets set overnight (details in Brady et al., 2007) and benthic macroinvertebrates were collected using D-frame dip nets in shallow water (one metre or less) and petit Ponar grabs offshore; only D-net samples from wetlands will be discussed here. Habitat data collected at each of 32 points randomly-allocated within each site included aspects of physical structure, vegetation, and human disturbance. Measured water quality variables included water clarity (Secchi depth), $\mathrm{pH}$, specific conductance, temperature, and dissolved oxygen concentration. Water quality parameters were measured at each sample location with a multi-probe YSI 556 calibrated daily. Selected Lake Superior fish and macroinvertebrate taxa (relative abundance) and metrics (representing assemblage structure [relative abundance]) as well as taxon traits (characterizing behavior, reproductive characteristics, and environmental tolerances) were regressed against five stress PCs (agriculture, atmospheric deposition, point sources, human population and development, and land cover) as well as the cumulative stress gradient. Macroinvertebrate taxa were identified to lowest practical level, generally genus for insects except Chironomidae (family); non-insects were identified to family or genus except Nematoda (phylum) and Oligochaeta (class). Macroinvertebrate tolerance values came primarily from Hilsenhoff (1987) and were supplemented by values from EPA (Barbour et al., 1999). 


\section{Wetland plants}

Emergent vegetation was sampled in 26 Lake Superior coastal wetlands. Sampling was done by visual cover estimation in $1 \times 1-\mathrm{m}$ plots distributed along randomly placed transects, using a protocol described by Johnston et al. (2007, 2008, 2009b). A data matrix was constructed of taxa cover for each of the 26 sites; taxa found at a minimum of two sites were retained. The taxon "invasive Typha," included both $T$. angustifolia and T. x glauca, but did not include the native species $T$. latifolia. Square root transformation was done to downweight high abundance species, and similarity was computed after Bray and Curtis (1957). Plant communities were classified by agglomerative hierarchical clustering with group-average linking based on Bray-Curtis similarities, and the SIMPER procedure was used to determine taxa contributions to the average similarity within each cluster (Clarke and Gorley, 2006). Non-metric multidimensional scaling (MDS) was used with the Bray-Curtis similarity data to ordinate sites, using 25 restarts and a minimum stress of 0.01 . All plant community analyses were conducted with PRIMER version 6 (Clarke and Gorley, 2006).

The floristic quality index (FQI) was computed for each site as a widely-tested metric of biological condition. The FQI computation weights plant species based on their "coefficient of conservatism" ( $C$ value), a zero-to-ten ranking of a species' fidelity to remnant natural plant communities:

$$
\mathrm{FQI}=\overline{\mathrm{C}} * \sqrt{ } \mathrm{N}
$$

where $[\overline{\mathrm{C}}]$ is mean coefficient of conservatism, and $\mathbf{N}$ is the number of species present (Boudaghs et al., 2006). State-specific $\bar{C}$ values were used for Wisconsin and Michigan (Bernthal, 2003; Herman et al., 2001); there were no vegetation study sites in Minnesota (Figure 1) due to the lack of emergent wetlands along its rocky coast. FQI was computed for each sample plot and averaged by site so as to reduce sampling area bias, after Bourdaghs et al. (2006).

\section{Soil and water quality data}

The soil at each vegetation sample plot was examined to a depth of 30 centimetres below the litter layer using a soil probe, and classified as organic or mineral (Johnston et al., 2007). The soil type that occurred in the majority of plots within a wetland was assigned to the wetland as a whole.

Water quality data were collected at all 35 diatom sites, all 32 coastal wetland fish-macroinvertebrate sites and 12 of the 26 Lake Superior vegetation sites by staff from the University of Minnesota Duluth (UMD) and the U.S. Environmental Protection Agency-Mid-Continent Ecology Division (MED) (Reavie et al., 2006; Reavie, 2007; Morrice et al., 2008). Data for a core suite of parameters (120 $\mathrm{cm}$ transparency tube clarity and Hydrolab or YSI multimeter sensors [temperature, dissolved oxygen, specific conductance, and $\mathrm{pH}]$ ) were collected at 0.5 $m$ depth intervals from surface to bottom. Water was collected from the point of sampling (for diatoms) and composited from three to six subsites for analytes including: total nitrogen (TN), total phosphorus (TP), ammonium nitrogen $\left(\mathrm{NH}_{4}{ }^{+}-\mathrm{N}\right)$, nitrite + nitrate nitrogen (hereafter referred to collectively as $\mathrm{NO}_{3}{ }^{-}-\mathrm{N}$ ), total suspended sediment (TSS), lab turbidity, chlorophyll $a(\mathrm{Chl} a)$, chloride $\left(\mathrm{Cl}^{-}\right)$, and dissolved organic carbon (DOC). Analytical techniques used by UMD and MED followed standard methods for low-level detection and were virtually identical as were quality assurance and quality control procedures. Details can be found in U.S. EPA (1983, 1991, and 1993), Ameel et al. (1998), APHA (2000), Reavie et al. (2006), and Morrice et al. (2008).

Twenty-five environmental variables derived from existing geospatial data sources were summarized for each site, all computed for our prior publications (Johnston et al., 2009a, 2009b). These included several integrated measures of watershed anthropogenic stress, derived by PCA of multiple stressors of a common anthropogenic origin, as described above (Danz et al., 2007): agriculture (PC1_AG), human population and development (PC1_URB), atmospheric deposition (PC1_ATDEP), point source pollution (PC1_NPDES), and the CSI. In addition, two integrated measures of watershed soil characteristics were used, related to soil texture (PC1_SOIL) and soil water availability, cation exchange capacity, and organic matter content (PC2_SOIL: Danz et al., 2005). Additional watershed variables used included total nitrogen and total phosphorus export (TN_export, TP_export) computed by SPARROW surface water quality modeling (Smith et al., 1997), human population calculated from U.S. Census data (POPU), cropland water erosion (EROS) calculated 
from National Resources Inventory data, and stream order (Strahler, 1957).

Development (DEV) and forest cover (FOR) were summarized for buffer areas of different widths (100-metres, 500-metres, 1000-metres, 5000-metres) around each wetland (Brazner et al., 2007b; Johnston et al., 2009b). The hydrologic modification index (HMI) was computed as the length per unit wetland area of within-wetland features that likely disrupt the natural flow and fluctuation of water within wetlands, such as road beds, dikes, and ditches (Bourdaghs et al., 2006; Johnston et al., 2008). In addition, each wetland was characterized by its area (WETL_AREA), latitude (LAT), and growing degree days (GDD).

Summary statistics and normality probability plots were computed for all water quality and environmental variables, and those with skewed distributions were log-transformed. A modified two-tailed t-test, intended for use with two samples having possibly unequal variances (Welch, 1947) was computed using the statistical software $R$, version 2.10.1 (The R Foundation for Statistical Computing, Vienna, Austria, http:/www.rproject.org/) to compare mean water quality and environmental parameters associated with the two major plant communities identified.

\section{Results}

Altogether, 89 Lake Superior coastal locations were sampled by GLEI investigators studying birds, diatoms, fish and macroinvertebrates, and wetland plants (Figure 1). In general, the U.S. Great Lakes coastal region of Lake Superior shows greater overall stress in the southern regions compared with relatively low overall stress in the northern regions (Figure 2). These patterns are primarily due to agricultural land use, higher human population densities, and point sources in the eastern and western portions on the south shore, while the north shore at the western end of Lake Superior is primarily forested with relatively sparse human population

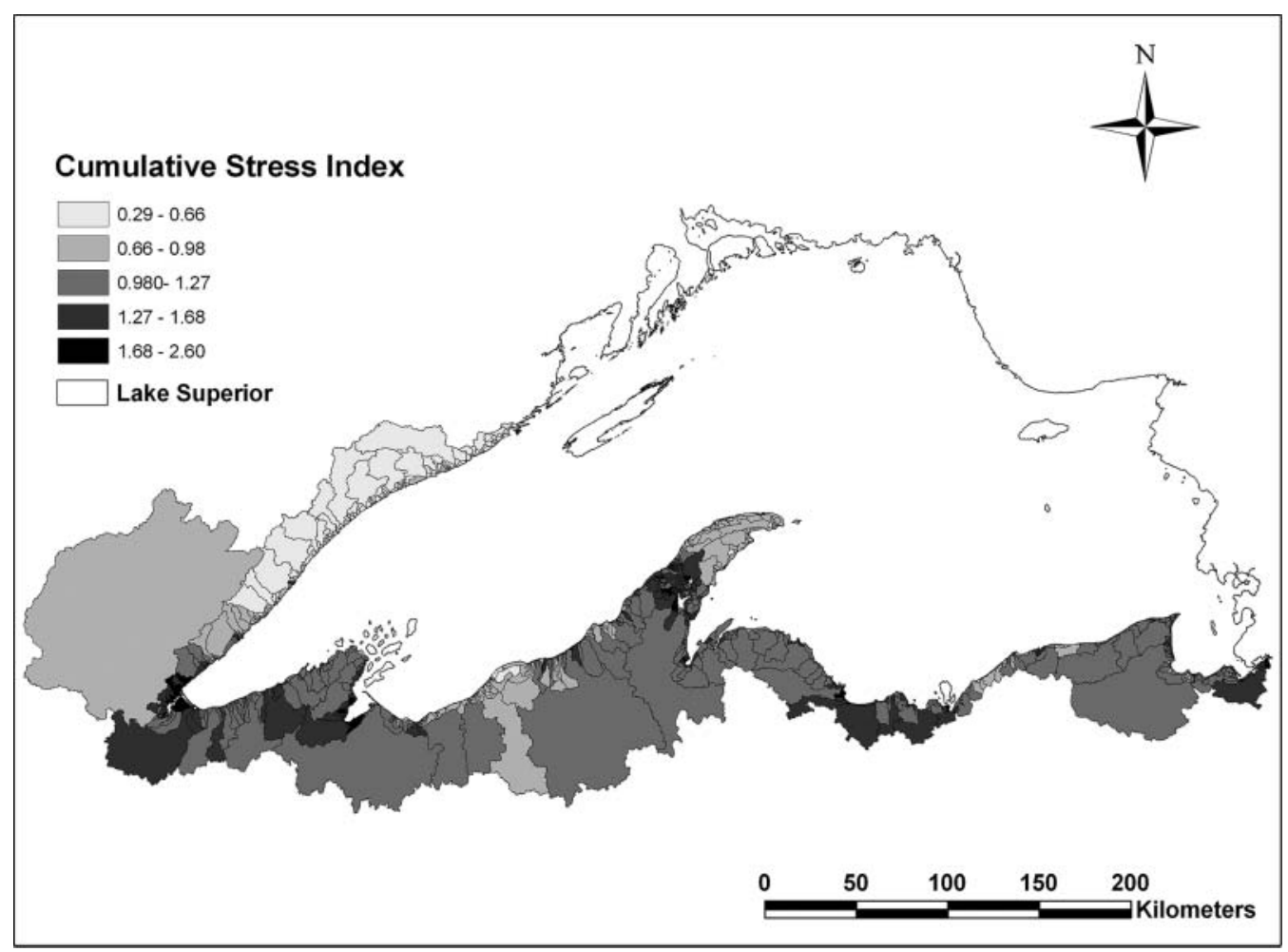

Figure 2. A cumulative stress index consisting of five component stress gradients (agriculture, human population, land cover, atmospheric deposition, and point source pollution; Danz et al., 2007) for Lake Superior watersheds. The index was created by scaling each gradient from $0-1$ (low to high stress) and summing. 
densities. For instance, land use in the coastal watersheds of Lake Superior varied from relatively pristine regions in the northwestern and selected southern coastal areas (e.g. Keweenaw Peninsula) to regions with moderate residential and industrial development such as near Duluth-Superior, (Minnesota-Wisconsin), Ashland, Wisconsin, Houghton-Hancock, Michigan, and Sault Ste. Marie, Michigan in the far eastern end (Figure 2).

\section{Landscape linkages reflected by ${ }^{15} \mathrm{~N}$ stable isotopes}

Watershed disturbance levels across the Lake Superior basin span a relatively narrow range compared to the full spectrum of conditions seen across the whole Great Lakes basin, and Lake Superior's coastal watersheds represent a very low to mediumlow level of disturbance in general. Peterson et al. (2007) used the basinwide gradient to demonstrate that watershed disturbances influence coastal receiving waters: landscape conditions and hydrologic flows downstream to coastal ecosystems produce a ${ }^{15} \mathrm{~N}$ isotope signal in biological tissues that integrate nutrient deliveries through food web/trophic pathways over time. Data from Peterson et al. (2007) do not provide sufficient power ( $\mathrm{n}=10$ sites $)$ to discern trends in Lake Superior alone, but by incorporating additional data for Lake Superior coastal sites, the updated results (Figure 3) suggest that a signif-

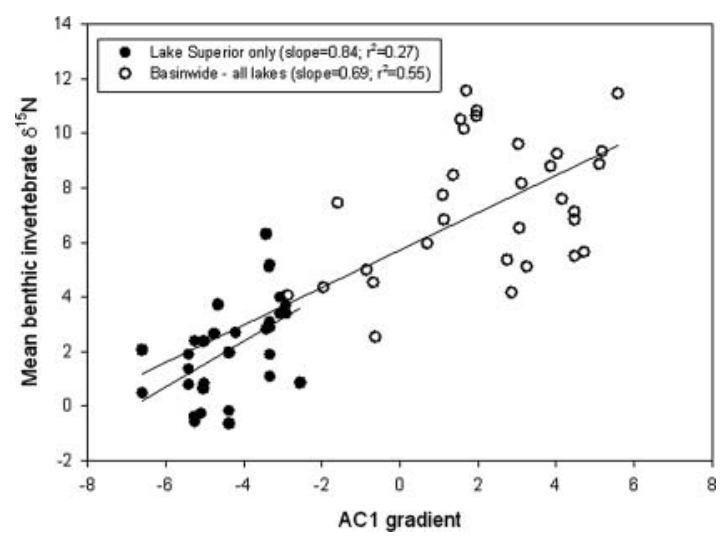

Figure 3. Mean benthic invertebrate $\delta^{15} \mathrm{~N}(\% 0)$ showing the relationship to $\mathrm{AC} 1$ (agriculture metric) stressor gradient for Great Lakes basinwide data set (data and regression from Peterson et al. 2007), with Lake Superior sites separately identified. We added 21 additional Lake Superior sites (nearshore, embayments, and coastal wetlands sampled from 2001-2004) to the 10 Lake Superior sites in the original data set. Both regression slopes are significant at $\mathrm{p} \leq 0.01$. icant linkage between coastal biota and landscape condition is evident even across the narrow watershed disturbance range - a result which is similar to and confirms the broader basinwide trend previously noted. Further, we found that ${ }^{15} \mathrm{~N}$ enrichment of benthic macroinvertebrates was significantly higher in Lake Superior coastal wetlands (mean $\delta^{15} \mathrm{~N}=3.2$ ) compared to embayments (mean $\delta^{15} \mathrm{~N}=1.7, \mathrm{p}=$ $0.011)$ and nearshore $\left(\right.$ mean $\left.\delta^{15} \mathrm{~N}=1.0, \mathrm{p}=0.004\right)$.

\section{Birds}

The IEC provides an estimate of wetland quality that is related to (through the biotic response functions of individual species) but more informative and ecologically relevant than measures of land use and human activity alone. In other words, species integrate the overall consequences of human impacts, so their occurrences tell us more about site quality than we could obtain simply analyzing physical or geographic variables. Bird species indicating high quality condition of Great Lakes coastal wetlands (Howe et al., 2007b) represent a variety of natural wetland types, including shallow marshes (Sedge Wren, Cistothorus platensis), wooded wetlands (Alder Flycatcher, Empidonax alnorum), and mixed upland-wetland mosaics (Bobolink, Dolichonyx oryzivorous). The IEC based on occurrences of multiple bird species therefore can provide information about the ecological condition of sites with a mosaic of vegetation attributes. Species adapted to agricultural or urbanized landscapes (e.g. Common Grackle, Quiscalus quiscala [Figure 4] and European Starling, Sturnis vulgaris) indicate lower quality conditions, whereas species restricted to relatively undisturbed wetlands (e.g. Sandhill Crane, Grus canadensis and Northern Harrier, Circus cyaneus) indicate high quality condition (Figure 4). Other species that were used in the calculations and their biotic response functions can be found in Howe et al. (2007b). Additional details about the occurrences of these and other species can be found in Niemi et al. (2006).

The environmental condition of Lake Superior coastal wetlands based on non-bird variables ranged from 1.8-10.0 (Figure 5). IEC based on birds, however, covered a much narrower range (6.2-9.8) within the gradient of possible values (zero-ten). In other words, in the context of all coastal wetlands in the Great Lakes, breeding birds in Lake Superior wetlands represented a higher quality assemblage of species than expected based on the degree 

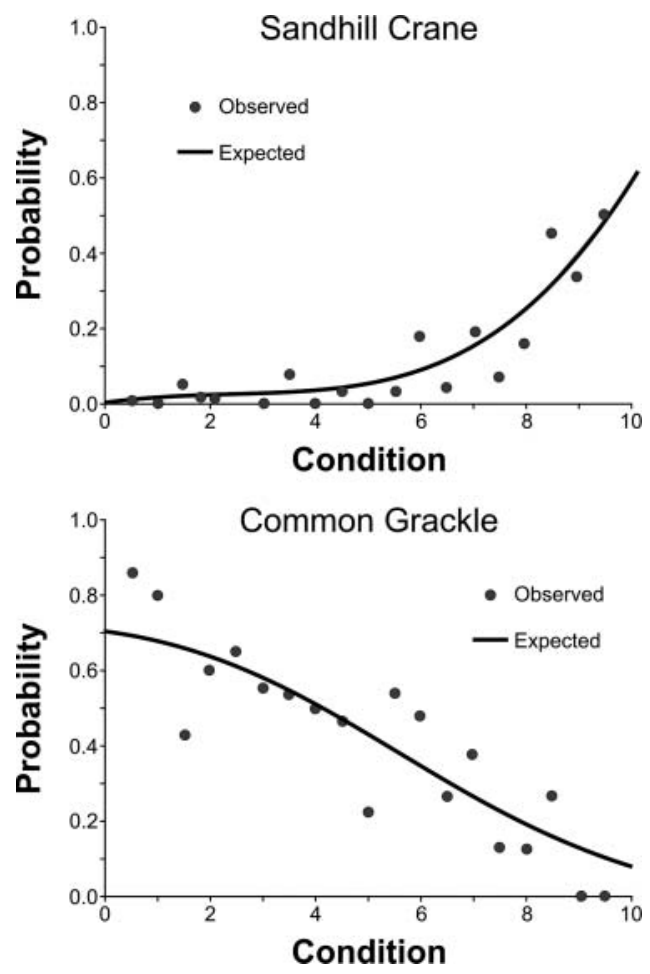

Figure 4. Species-specific responses to environmental condition for Sandhill Crane, a wetland sensitive species, and Common Grackle, a tolerant species. Probability (y-axis) is the probability of observing the species in a coastal wetland during a $15-\mathrm{min}$ breeding season point count. Condition is based on a multivariate analysis of land cover and other environmental variables, where 0 $=$ highly impacted by human activities (maximally stressed) and $10=$ least impacted by human activities (minimally stressed). Solid line represents the expected probability based on the bestfit logistic function described by Howe et al. (2007a).

of human impacts in the surrounding landscape. Overall, bird-based IECs in Lake Superior wetlands were significantly higher than values from all other Great Lakes (Figure 5, P $<0.001$ ). In fact, sites from Lake Superior showed little or no relationship with environmental condition, reflecting the fact that species absent or rare in highly impacted wetlands elsewhere in the Great Lakes (e.g. Alder Flycatcher, Sedge Wren, Swamp Sparrow [Melospiza georgiana], and White-Throated Sparrow [Zonotrichia alibicollis]) were widely distributed in coastal wetlands of Lake Superior, even those where the human "footprint" was relatively significant.

\section{Diatoms}

Based on independent comparisons of measured and diatom-inferred environmental data derived us-

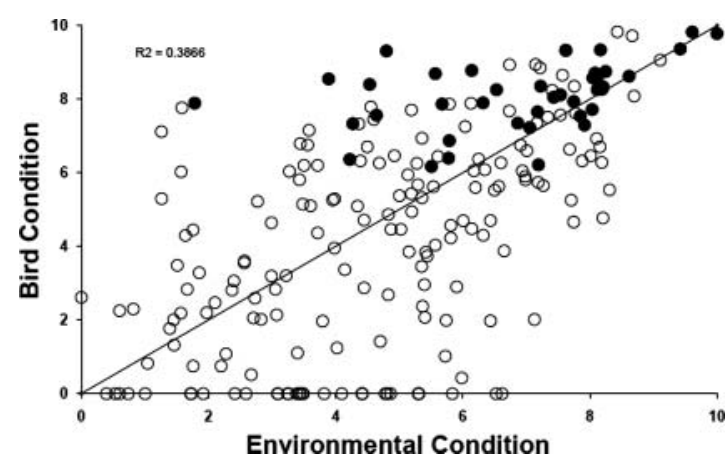

Figure 5. Relationship between index of ecological condition (IEC) in coastal wetlands, based on presence absence of 23 indicator bird species (Bird Condition), and Reference Condition, based on land use and other variables associated with anthropogenic stress. Values for Superior (solid circles) are shown with values (open circles) for wetlands of Lakes Michigan, Huron, Erie, and Ontario.

ing the diatom-based WA models, the transfer functions provided robust reconstructions of phosphorus and solids concentrations along Great Lakes coastlines (Reavie et al., 2006; Reavie, 2007; Kireta et al., 2007). Also, diatom indicators were strongly correlated with watershed characteristics (Figure 6). The magnitude of the correlations between diatominferred water quality and stressors exceeded correlations to measured water quality, indicating that diatom-based reconstructions better tracked anthropogenic impacts than point measurements of water quality. Because coastal algae reside adjacent to each shoreline reach and are relatively insensitive to unpredictable fluctuations (as can be the case for snapshot chemical measurements), the diatom assemblage integrates environmental information.

Although Lake Superior captured a lower, narrower nutrient gradient relative to the complete set of Great Lakes locations, diatom-based approaches were still able to detect differences in the lake. Lake Superior was represented in the lowest third of the Great Lakes agricultural stress gradient; yet even within this narrow region there was a significant correlation between both DI TP and DI TSS and agricultural influence (Figure 6, left panels). Lake Superior captured a low to midrange portion of the urban development gradient. Increased DI TP and DI TSS were significantly related to increasing urban conditions in the Lake Superior basin, whereas there was no significant correlation between DI water quality and urban development when the full set of Great Lakes locations was considered (Figure 6 , middle panel). As for the complete set of 

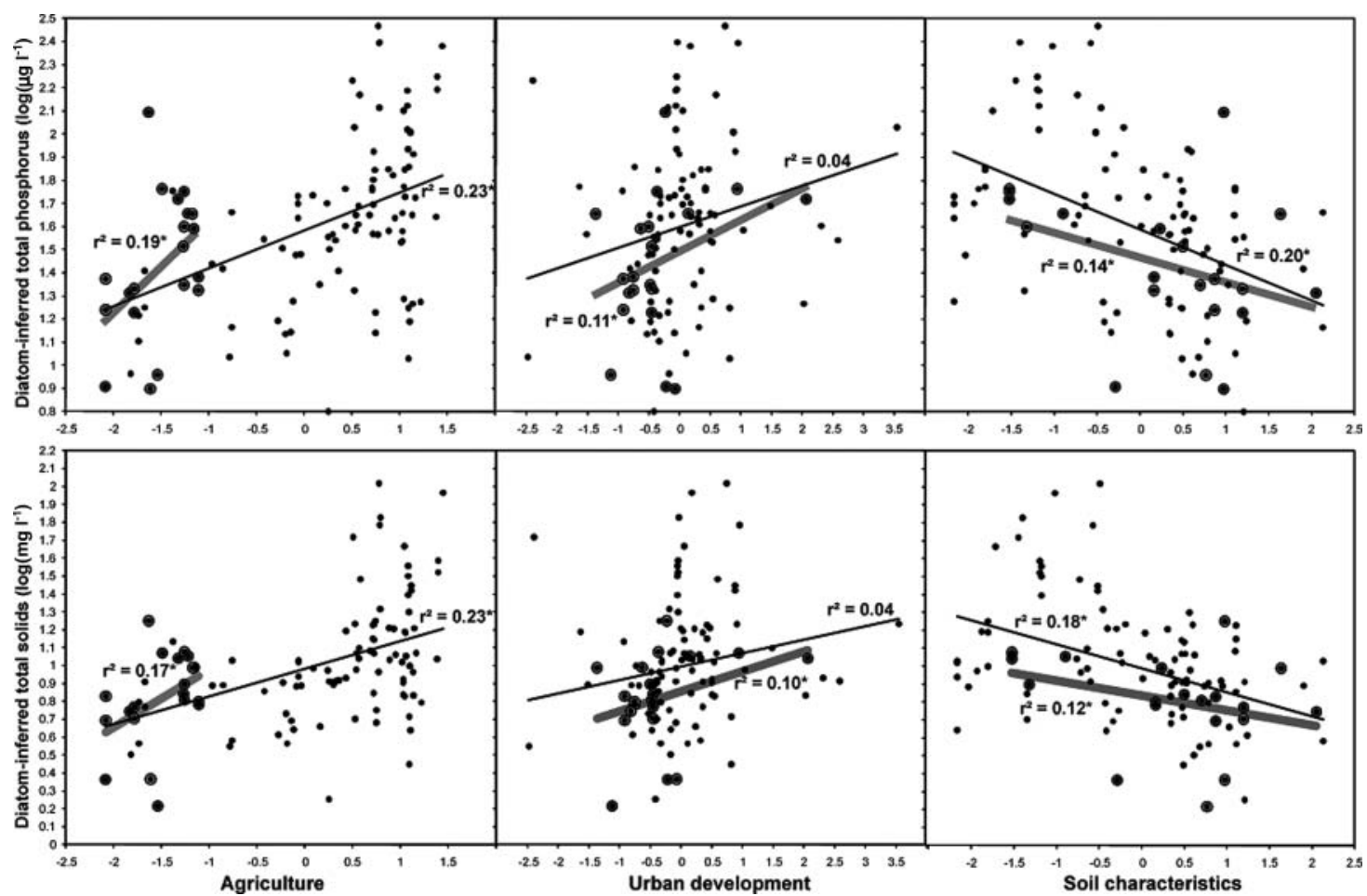

Figure 6. Three watershed characteristics (unitless scores derived from principal components analysis) for Great Lakes coastal locations regressed against diatom-inferred total phosphorus concentrations. Encircled samples are from Lake Superior. Linear regression lines are shown for all five Great Lakes (black line) and Lake Superior (gray line). Significant $(\mathrm{P}<0.05)$ squared correlation coefficients $\left(\mathrm{r}^{2}\right)$ for each regression are marked with asterisks.

Great Lakes locations, DI TP and DI TSS showed significant correlations to soil characteristics across the basin (Figure 6, right panels). The diatoms have clear responses to water quality and anthropogenic stressors in Lake Superior's watershed, so monitoring and management is likely to benefit from diatom assessments in the future.

\section{Fish}

Twenty-two fish species were detected across Lake Superior coastal habitats: ten species were found exclusively in high energy sites, ten were exclusive to riverine wetlands, and one each were found exclusively in protected and open coastal wetlands. Riverine wetlands had the most species, while bays had the most non-native (exotic) species. All species commonly found in protected wetlands were also common in riverine wetlands; similarly, most of the species encountered in open coastal wetlands were also found in bays.

Fish community characteristics varied across the five ecosystem types we studied. In general, the wet- lands contained more species tolerant of turbidity and warmer temperatures, exhibited nest-guarding behavior, supported top carnivores or herbivores, and had a majority of species that grow to large body sizes $(>60 \mathrm{~cm})$. The high energy shoreline habitats, in contrast, supported species that tended to have smaller body sizes and were bottom-feeders. Nest guarding fish (e.g. Lepomis spp., Pomoxis spp., Ameriurus melas) were frequently most abundant in open coastal wetlands and protected wetlands, although they also occurred in riverine wetlands.

In general, human activity and other disturbances at a site were most strongly associated with higher levels of suspended solids (Trebitz et al., 2007a). Fish taxa at these sites were dominated by exotic species (Eurasian Ruffe [Gymnocephalus cernuus] and European Carp [Cyprinus carpio]) and species tolerant of turbid conditions (Northern Pike [Esox lucius], Northern Mimic Shiner [Notropis volucellus], and Central Mud-Minnows [Umbra limi]). High energy sites showing high levels of human activity were dominated by Eurasian Ruffe, and species such as Green Sunfish (Lepomis cyanellus) 


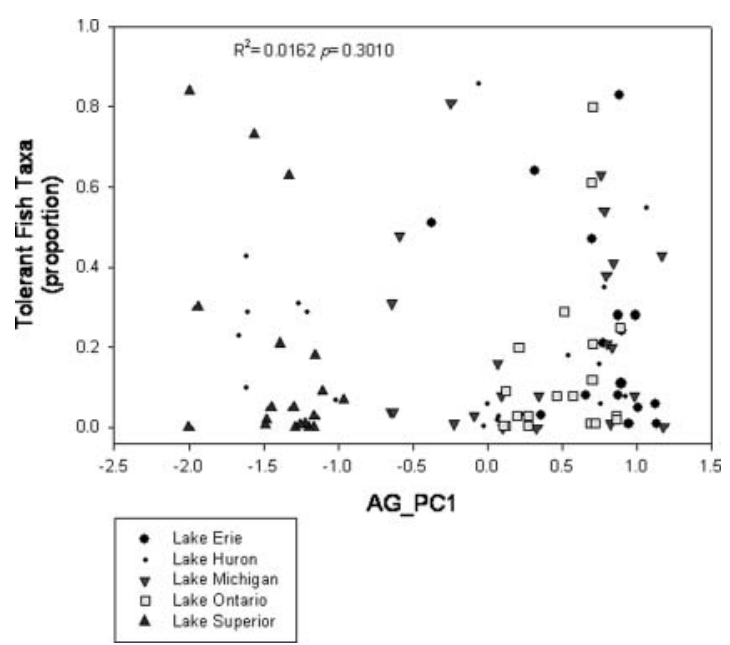

Figure 7. Proportion of tolerant fish taxa in Great Lakes wetlands with respect to the AG-PC axis. Note the "U"-shaped distribution across the basin as a whole.

and Spottail Shiner (Notropis hudsonius), with the community being dominated by omnivorous taxa. Sites that were located within watersheds with little human disturbance were characterized by a greater proportion of bottom-feeding taxa (e.g. white sucker [Catostomus commersoni] and burbot [Lota lota]). Wetlands and bays with deep organic sediments had fewer taxa per site, and fewer native species. When combined with turbid water, these types of sites also contained a higher proportion of exotic species.

In Lake Superior, few significant relationships were observed between fish assemblage metrics and the disturbance axis scores. Across the basin, the relationship between the Ag-PC 1 and the proportion of tolerant fish taxa was strongly "U"-shaped (Figure 7). In Lakes Erie and Michigan the relationship was strongly negative, while in Lake Superior there was a negative wedge-shaped distribution. This suggests multiple factors influence the distribution of tolerant fish species at sites with the lowest Ag-PC scores. In contrast, across the Great Lakes basin, bluegill (Lepomis macrochirus) and carp (Cyprinus carpio)+goldfish (Carassius auratus) were found to be consistent indicators of disturbance, while rock bass (Ambloplites rupestris) were found to be associated with less disturbance (Brazner et al., 2007a, 2007b). Two community metrics, the proportion of turbidity-intolerant fish species and the proportion of nest-guarding species, also were found to be associated with relatively low amounts of disturbance across the entire Great Lakes basin (Brazner et al., 2007a). However, it appears that in Lake Superior the length of the disturbance gradient is not sufficient to establish reliable metrics for use as indicators for long-term trend detection.

There are some marked differences in Lake Superior coastal fish communities compared to the other Great Lakes. Based on pairwise comparisons, Lake Superior had more intolerant species and more "intolerant" individuals than all of the other lakes combined (Table 1). In particular, there were more species considered intolerant of high turbidity (Trebitz et al., 2007b). Specifically, Lake Superior had significantly more intolerant species than lakes Michigan, Erie, or Ontario. It differed from Lake Erie in having more intolerant species as well as a greater abundance of intolerant individuals. Similar patterns were found with respect to the abundance of turbidity intolerant species. Finally, the abundance of nest-guarding fish was lower in Lake Superior than in Lake Erie. When the individual geomorphic types were compared across the lakes, we found somewhat similar patterns for high energy and riverine wetlands (Table 1). Interestingly, protected wetlands in Lake Superior did not differ from those of other lakes in terms of their community characteristics. Since we sampled only two open coastal wetlands in Lake Superior, we could not detect significant differences with respect to the other lakes; however, a qualitative comparison suggests that these ecosystems were similar to protected wetlands in many respects.

\section{Invertebrate community composition}

Lake Superior wetland macroinvertebrate communities were composed of an average of 34 taxa (with Chironomidae identified only to the family level). Of these, an average of seven taxa (22 percent) was from the relatively intolerant orders composed of mayflies (Ephemeroptera), caddisflies (Trichoptera), and dragonflies and damselflies (Odonata). Community composition was dominated by Diptera (true flies; mean 27\%) and relatively intolerant groups (Ephemeroptera, Trichoptera, and Odonata) made up an average of 11 percent of invertebrate abundance.

In contrast to fish, for which individual metrics or species were found to respond to stress over large geographic ranges, invertebrate community indicator patterns behaved consistently only within particular ecoregion and geomorphic types (L. Johnson et al., Natural Resources Research Institute, University of Minnesota Duluth, USA, unpublished data). 
Table 1. Comparison of fish community metrics in Lake Superior versus the other Great Lake coastal ecosystems. The community traits reflect the relative abundance of fish with particular characteristics. Abbreviations: RW = riverine wetland, $\mathrm{HE}=$ high energy shore, $\mathrm{CW}=$ open coastal wetland, $\mathrm{PW}=$ barrier beach protected wetland, $\mathrm{EB}=$ embayments. (Adapted from: Johnson et al., 2008.)

\begin{tabular}{|c|c|c|c|c|}
\hline & $\begin{array}{l}\text { Compared to } \\
\text { all Great Lakes } \\
\text { combined }\end{array}$ & $\begin{array}{l}\text { Compared to } \\
\text { other Great Lakes } \\
\text { taken individually }\end{array}$ & $\begin{array}{l}\text { Compared to similar } \\
\text { ecosystem types in all } \\
\text { Great Lakes combined }\end{array}$ & $\begin{array}{l}\text { Compared to similar } \\
\text { ecosystem types in } \\
\text { other Great Lakes }\end{array}$ \\
\hline \multicolumn{5}{|c|}{ Community composition } \\
\hline \multirow[t]{2}{*}{$\begin{array}{l}\text { \# Intolerant } \\
\text { species }\end{array}$} & Superior $>$ & $\begin{array}{l}\text { Superior } \\
\gg \text { Michigan, } \\
\text { Erie, Ontario }\end{array}$ & RW: Superior $>$ & \multirow[t]{3}{*}{$\begin{array}{l}\text { RW: Superior } \gg \\
\text { Michigan, Erie, } \\
\text { Ontario }\end{array}$} \\
\hline & & & $\begin{array}{l}\text { PW: Superior > } \\
\text { HE: Superior }>\end{array}$ & \\
\hline $\begin{array}{l}\text { \# Non-native } \\
\text { species }\end{array}$ & & Superior $<$ Erie & & \\
\hline \multicolumn{5}{|c|}{ Community traits } \\
\hline $\begin{array}{l}\% \text { Intolerant } \\
\text { individuals } \\
\% \text { Tolerant } \\
\text { individuals }\end{array}$ & Superior $>$ & Superior $>$ Erie & RW: Superior > & \multirow[t]{2}{*}{$\begin{array}{l}\text { RW: Superior }> \\
\text { Michigan } \\
\text { HE: Superior }<\text { Huron }\end{array}$} \\
\hline $\begin{array}{l}\text { \% Turbidity } \\
\text { intolerant }\end{array}$ & Superior $>$ & Superior $>$ Erie & RW: Superior > & \\
\hline \multirow{4}{*}{$\begin{array}{l}\% \text { Non-native } \\
\% \\
\text { Nestguarding }\end{array}$} & & Superior $<$ Erie & & \multirow[t]{4}{*}{ RW: Superior < Erie } \\
\hline & & Superior $<$ & CW: Superior > & \\
\hline & & Ontario & & \\
\hline & & & EB: Superior < & \\
\hline
\end{tabular}

Although the agricultural gradient is truncated for Lake Superior relative to the other Great Lakes, several invertebrate taxonomic, behavioral, and feeding groups responded negatively to increased amounts of agriculture in the watershed. The proportions of Diptera (Figure 8a), burrowing invertebrates, and invertebrates that feed by filtering particles from the water (filter-gatherers) (graphs almost identical to Figure $8 \mathrm{a}$ ) were negatively correlated with increased proportion of agriculture $(r=-0.67, \mathrm{p}=$ 0.007 ), as was odonate taxa richness (Figure $8 \mathrm{~b} ; r=$ $-0.53, \mathrm{p}<0.05)$. There were no strong correlations with urban land use, likely because we sampled few wetland sites in urbanized watersheds in Lake Superior compared with other Great Lakes.

\section{Wetland vegetation}

There were 126 plant taxa that occurred in two or more of the Lake Superior wetlands sampled. Hierarchical clustering and MDS analysis divided the Lake Superior coastal wetland plant communities into three groups that were distinct from each other at a 30 percent similarity threshold
(Figure 9): northern poor fens, burreed/lake sedge, and bluejoint/tussock sedge. Northern poor fens are vegetated by woolly-fruit sedge and various ericaceous shrubs growing in a carpet of Sphagnum moss, whereas burreed/lake sedge marshes contain broadfruit burreed, several sedge species, arrowhead, and broadleaf cattail (Table 2). The bluejoint/tussock sedge community, dominated by Calamagrostis canadensis and Carex stricta, was represented by a single wetland, the easternmost site that we studied on Lake Superior. The mean FQI value for the northern poor fen wetlands was significantly greater than that for the burreed/lake sedge wetlands (Table 2), consistent with previous findings (Bourdaghs, 2006; Johnston et al., 2009b).

We were surprised that broadleaf cattail (T. latifolia) was among the most frequent species, occurring at 21 of the 26 sites, because cattail is a genus that is not usually associated with Lake Superior wetlands (Epstein et al., 1997). However, where present, the cover of broadleaf cattail was relatively low (mean $=$ $3.2 \%$, maximum $=14.8 \%$ ). By comparison, woollyfruit sedge occurred at 19 sites and covered a high proportion of the site $($ mean $=14.0 \%$, maximum $=$ 
Table 2. Species contributing to average percent similarity within northern poor fen and burreed/lake sedge plant communities in Lake Superior. Data shown for taxa contributing $2.5 \%$ or more to average similarity.

\begin{tabular}{|c|c|c|c|}
\hline Scientific name & Common name & $\begin{array}{l}\text { Northern } \\
\text { poor fen }\end{array}$ & $\begin{array}{l}\text { Burreed/ } \\
\text { lake sedge }\end{array}$ \\
\hline${ }^{\mathrm{a} A n d r o m e d a}$ polifolia var. glaucophylla & Bog rosemary & 5.5 & \\
\hline${ }^{\mathrm{b}}$ Calla palustris & Water arum & & 4.1 \\
\hline Carex lacustris & Lake sedge & & 11.2 \\
\hline${ }^{\mathrm{a} C a r e x ~ l a s i o c a r p a}$ var. americana & American woollyfruit sedge & 13.4 & \\
\hline Carex stricta & Tussock sedge & & 4.7 \\
\hline${ }^{\mathrm{b}}$ Carex utriculata & Northwest Territory sedge & & 4.3 \\
\hline${ }^{\mathrm{a} C h a m a e d a p h n e ~ c a l y c u l a t a}$ & Leatherleaf & 7.0 & \\
\hline${ }^{\mathrm{a} C l a d i u m ~ m a r i s c o i d e s}$ & Smooth sawgrass & 3.2 & \\
\hline${ }^{\mathrm{b}}$ Comarum palustre & Purple marshlocks & & 6.0 \\
\hline${ }^{\mathrm{a}}$ Drosera rotundifolia & Roundleaf sundew & 3.4 & \\
\hline${ }^{\mathrm{a}}$ Menyanthes trifoliata & Buckbean & 6.5 & \\
\hline${ }^{\mathrm{a}}$ Myrica gale & Sweetgale & 12.8 & 2.9 \\
\hline${ }^{\mathrm{b}}$ Sagittaria graminea & Grassy arrowhead & & 3.1 \\
\hline${ }^{\mathrm{b}}$ Sagittaria latifolia & Broadleaf arrowhead & & 7.3 \\
\hline a Sarracenia purpurea & Purple pitcherplant & 3.8 & \\
\hline bparganium eurycarpum & Broadfruit burreed & & 12.7 \\
\hline a Sphagnum spp. & Sphagnum moss & 13.0 & \\
\hline Typha latifolia & Broadleaf cattail & & 6.1 \\
\hline${ }^{\mathrm{a}}$ Vaccinium oxycoccos & Small cranberry & 2.8 & \\
\hline Average similarity & & 49.7 & 37.5 \\
\hline Number of sites & & 8 & 17 \\
\hline
\end{tabular}

${ }^{\mathrm{a}}=$ species that are organic soil indicator species, ${ }^{\mathrm{b}}=$ species that are clay or silt soil indicator species (Johnston et al., 2007).

48.6\%). In addition to the taxa that contributed to the similarity within the northern poor fens and the burreed/lake sedge communities (Table 2), five plant species occurred at 16 or more Lake Superior sites, Galium trifidum, Cicuta bulbifera, Equisetum flu- viatile, Calamagrostis canadensis, and Lysimachia thyrsiflora.

Based on our previous MDS analysis of Great Lakes coastal wetland vegetation (Johnston et al., 2009b), we knew that Lake Superior wetlands

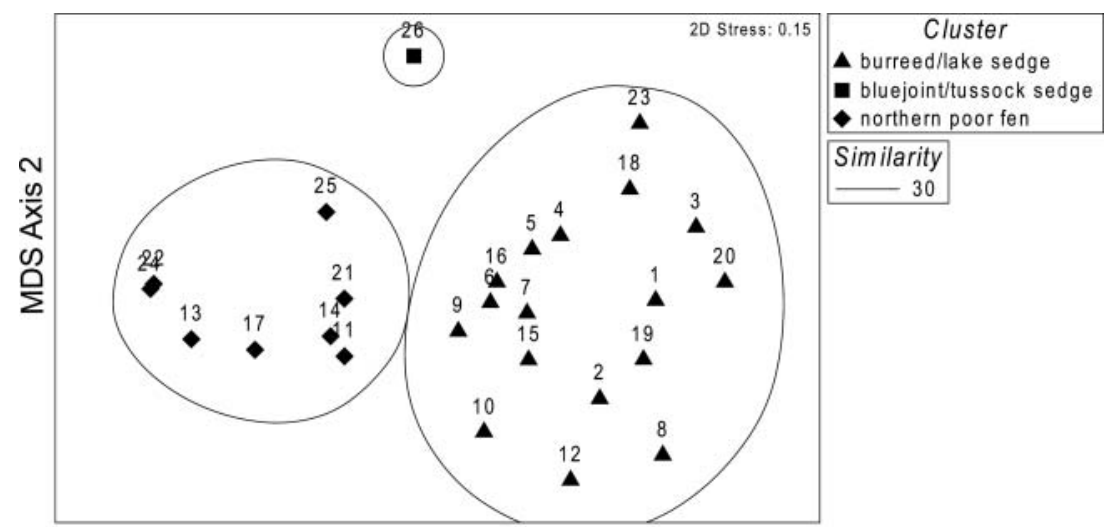

MDS Axis 1

Figure 9. Lake Superior coastal wetlands plotted relative to the first (x axis) and second (y axis) MDS axes, classified by vegetation hierarchical cluster. Labels are site numbers, increasing from west to east along the southern Lake Superior coast (see map in Figure 3 of Johnston et al., 2009b). 

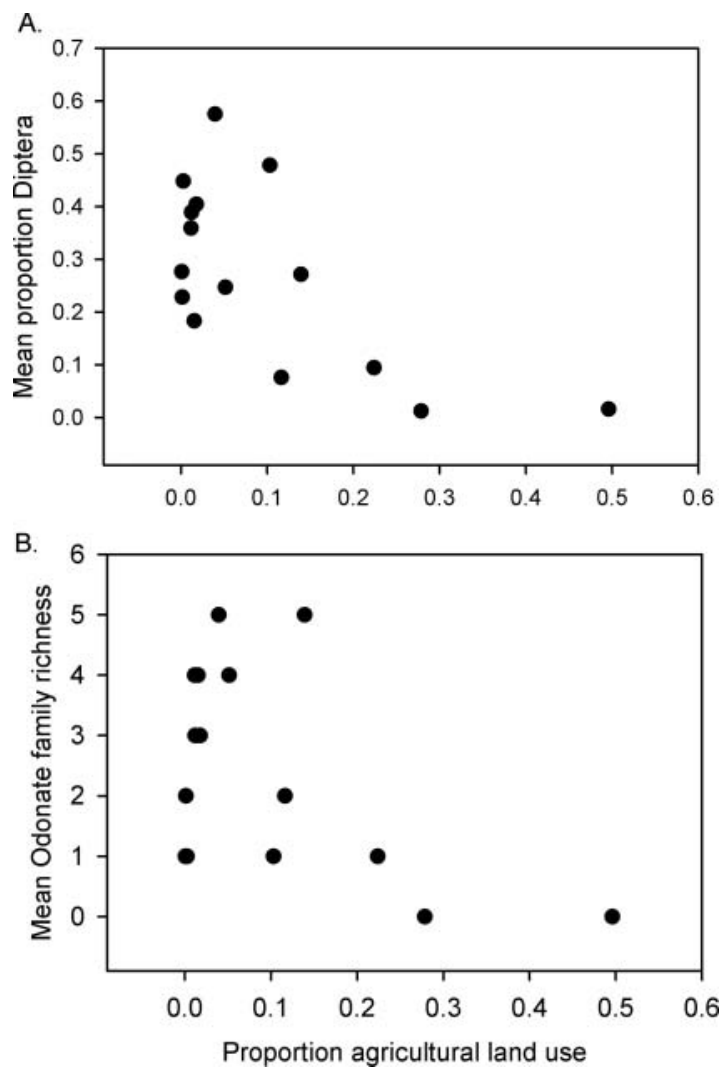

Figure 8. A. Proportion of Diptera (true flies) and B. mean Odonate family richness as a function of the proportion of agricultural land use in the U.S. Lake Superior basin.

spanned the least degraded two-thirds of the range of vegetation condition, represented by the MDS first axis scores (Figure 9). Honest John Lake and Lightfoot Bay (sites 22, 24), at the extreme left of the MDS graph, had the least degraded floristic condition, whereas Prentice Park near Ashland, Wisconsin had the most degraded (site 20). Prentice Park had been previously identified as experiencing greater anthropogenic stress than other Lake Superior wetlands by our classification and regression tree (CART) model of the 90-wetland dataset (Johnston et al., 2009b).

There were several soil and physiographic differences between the northern poor fens and the burreed/lake sedge sites. Most of the northern poor fens (6 of 8) were in the "protected" hydrogeomorphic class, whereas most of the burreed/lake sedge wetlands (12 out of 17) were "riverine." All eight of the northern poor fen sites had organic soils, whereas 14 of the 17 burreed/lake sedge sites had mineral soils. All of the species that contributed to the sim- ilarity of northern poor fens were organic soil indicators and most of the species that contributed to the similarity of burreed/lake sedge wetlands were clay or silt indicators (Table 2). Northern poor fens occurred in areas with a significantly shorter growing season (based on GDD) than did burreed/lake sedge wetlands (Table 3). Although not statistically significant, there was a tendency for northern poor fens to have larger wetland areas, smaller watersheds, and be on smaller-order streams than burreed/lake sedge wetlands. Thus, the two wetland environments are geomorphically and physiographically distinct.

Disturbance and water chemistry metrics showed that burreed/lake sedge wetlands had significantly greater hydrologic modification (HMI), specific conductance, total P, and TSS (Table 3) than the poor fens. In addition, burreed/lake sedge wetlands were subject to greater anthropogenic disturbance from their watersheds, as quantified by larger cumulative stress (CSI), total phosphorus (TP_export), total nitrogen (TN_export), and the fraction of the 5000-metre buffer that was developed (DEV_5000). There was significantly less forest in the 100-metre buffer (FOR_100) surrounding northern poor fens, which tended to abut lakes and other wetlands. Agricultural disturbance was minimal; there were no row crops within the watersheds of any of the Lake Superior wetlands, and PC1_AG scores were very negative, indicating little agricultural activity.

\section{Discussion}

The stress gradients for the U.S. portion of the Lake Superior coastal watershed was the second shortest for proportion of agricultural area (Lake Ontario was the lowest) and relative atmospheric deposition (Lake Erie was lowest), the second longest gradient of human population density (Lake Michigan had the longest), and was intermediate for cumulative stress index compared with the other four lakes (Niemi et al., 2009; Table 2). Coastal regions of Lake Superior can be found at each of the extremes of the disturbance gradients. This includes relatively pristine watersheds in the northern regions with low human population densities and little agriculture that contrast with regions of relatively high populations with industrial activity such as Duluth-Superior in Minnesota-Wisconsin and Sault Ste. Marie, Michigan at the other end of the gradient. The U.S. Lake Superior coastal region varies 
Table 3. Comparison of poor fen and burreed/lake sedge floristic quality and environmental properties in Lake Superior. FQI = floristic quality index, $\mathrm{TN}=$ total nitrogen, $\mathrm{NO}_{3}-\mathrm{N}=$ nitrite + nitrate nitrogen, $\mathrm{NH}_{4}-\mathrm{N}=$ ammonium nitrogen, $\mathrm{TP}=$ total phosphorus, TSS $=$ total suspended solids, TURB $=$ turbidity, DOC $=$ dissolved organic carbon, Chl $a=$ chlorophyll $a$, COND $=$ specific conductance, $\mathrm{Cl}^{-}=$chloride, $\mathrm{DO}=$ dissolved oxygen, $\mathrm{HMI}=$ hydrologic modification index, WETL_AREA $=$ wetland area, LAT $=$ latitude, GDD = growing degree days, SHED_AREA = watershed area, CSI = cumulative stress index, STRAHLER $=$ Strahler stream order, $\mathrm{POPU}=$ watershed human population, $\mathrm{PC} 1 \_\mathrm{AG}=$ agricultural principal component, PC1_URB $=$ urban principal component, PC1_ATDEP = atmospheric deposition principal component, PC1_NPDES = point-source pollution principal component, PC1_SOIL = first soil principal component, PC2_SOIL = second soil principal component, EROS = watershed erosion, TP_export $=$ watershed total phosphorus export, TN_export $=$ watershed total nitrogen export, DEV_100 = urban development within $100 \mathrm{~m}$ buffer around wetland, FOR_100 = forest within $100 \mathrm{~m}$ buffer around wetland, $\dagger=$ data values were log-transformed prior to calculations and values reported for these are geometric means, ${ }^{*} \mathrm{p}<0.05,{ }^{* *} \mathrm{p}<0.01,{ }^{* * *} \mathrm{p}<0.001$.

\begin{tabular}{|c|c|c|c|c|c|c|c|}
\hline \multirow[b]{2}{*}{ Parameter } & \multirow[b]{2}{*}{ Units } & \multicolumn{3}{|c|}{ Mean value } & \multicolumn{3}{|c|}{ Statistical results } \\
\hline & & & $\begin{array}{l}\text { reed/lake } \\
\text { sedge }\end{array}$ & Poor fen & $\mathrm{t}$ & df & $\mathrm{p}$ \\
\hline \multicolumn{8}{|c|}{ Within-wetland metrics: } \\
\hline${ }^{\mathrm{a}} \mathrm{FQI}$ & unitless & & 14.59 & 23.21 & -7.23 & 14.27 & $0.000^{* * *}$ \\
\hline $\mathrm{TN}$ & $\mu \mathrm{g} 1^{-1}$ & $\dagger$ & 402.65 & 457.36 & -0.36 & 8.07 & 0.728 \\
\hline${ }^{b} \mathrm{NO}_{3}{ }_{-} \mathrm{N}$ & $\mu \mathrm{g}^{-1}$ & $\dagger$ & 25.02 & 11.69 & 1.32 & 9.38 & 0.217 \\
\hline${ }^{b} \mathrm{NH}_{4}{ }_{-} \mathrm{N}$ & $\mu \mathrm{g}^{-1}$ & $\dagger$ & 10.01 & 10.09 & -0.02 & 7.06 & 0.984 \\
\hline${ }^{\mathrm{b}} \mathrm{TP}$ & $\mu \mathrm{g}^{-1}$ & $\dagger$ & 34.72 & 18.31 & 2.81 & 8.71 & $0.021^{*}$ \\
\hline${ }^{\mathrm{b}} \mathrm{TSS}$ & $\mathrm{mg} \mathrm{l}^{-1}$ & $\dagger$ & 7.32 & 4.10 & 3.01 & 9.85 & $0.013^{*}$ \\
\hline${ }^{\mathrm{c}}$ TURB & NTU & $\dagger$ & 8.78 & 3.71 & 1.80 & 9.83 & 0.102 \\
\hline${ }^{b} \mathrm{DOC}$ & $\mathrm{mg}^{-1}$ & $\dagger$ & 6.83 & 10.63 & -0.88 & 8.59 & 0.405 \\
\hline${ }^{\mathrm{b}} \mathrm{Chl} \_\mathrm{a}$ & $\mu \mathrm{g}^{-1}$ & $\dagger$ & 3.07 & 4.13 & -0.67 & 8.90 & 0.522 \\
\hline${ }^{\mathrm{c}} \mathrm{COND}$ & $\mathrm{uS} \mathrm{cm} \mathrm{cm}^{-1}$ & $\dagger$ & 142.42 & 91.49 & 3.03 & 9.01 & $0.014^{*}$ \\
\hline${ }^{\mathrm{b}} \mathrm{Cl}^{-}$ & $\mathrm{mg}^{-1}$ & $\dagger$ & 4.00 & 1.81 & 2.12 & 9.60 & 0.061 \\
\hline${ }^{\mathrm{c}} \mathrm{DO}$ & $\mathrm{mg} \mathrm{l}^{-1}$ & $\dagger$ & 7.60 & 7.53 & 0.07 & 9.37 & 0.945 \\
\hline${ }^{\mathrm{c}} \mathrm{pH}$ & - & & 7.71 & 7.41 & 1.51 & 6.49 & 0.177 \\
\hline${ }^{\mathrm{d}} \mathrm{HMI}$ & $\mathrm{m} \mathrm{ha}^{-1}$ & $\dagger$ & 10.29 & 3.06 & 2.44 & 20.10 & $0.024^{*}$ \\
\hline${ }^{\mathrm{e} W E T L}$ _AREA & $\mathrm{ha}^{-1}$ & $\dagger$ & 27.5 & 112.48 & -2.08 & 9.86 & 0.064 \\
\hline${ }^{\mathrm{a}} \mathrm{LAT}$ & degrees & & 46.70 & 46.73 & -0.58 & 8.39 & 0.576 \\
\hline${ }^{\mathrm{a}} \mathrm{GDD}$ & ${ }^{\circ} \mathrm{C}$ & & 1643.06 & 1598.63 & 2.52 & 12.52 & $0.026^{*}$ \\
\hline \multicolumn{8}{|l|}{ Landscape metrics: } \\
\hline e'SHED_AREA & $\mathrm{ha}^{-1}$ & $\dagger$ & 6742.45 & 1464.3 & 1.82 & 15.17 & 0.088 \\
\hline${ }^{\mathrm{f}} \mathrm{CSI}$ & unitless & & 1.51 & 1.21 & 2.91 & 12.08 & $0.013^{*}$ \\
\hline${ }^{\text {aSTRAHLER }}$ & unitless & & 3.18 & 1.75 & 2.12 & 13.56 & 0.053 \\
\hline${ }^{\mathrm{a} P O P U}$ & count & $\dagger$ & 334.42 & 51.22 & 2.03 & 21.11 & 0.055 \\
\hline${ }^{\mathrm{f}} \mathrm{PC} 1 \_\mathrm{AG}$ & unitless & & -1.30 & -1.36 & 0.56 & 12.39 & 0.583 \\
\hline fPC1_URB & unitless & & -0.55 & -0.48 & -0.25 & 19.98 & 0.806 \\
\hline${ }^{\mathrm{f}} \mathrm{PC} 1 \_\mathrm{ATDEP}$ & unitless & & -1.40 & -1.20 & -1.99 & 18.56 & 0.062 \\
\hline fPC1_NPDES & unitless & & 0.75 & 0.01 & 1.35 & 16.00 & 0.197 \\
\hline gPC1_SOIL & unitless & & -0.30 & -0.41 & 0.23 & 11.72 & 0.825 \\
\hline${ }^{g} \mathrm{PC} 2 \_\mathrm{SOIL}$ & unitless & & 0.81 & 0.91 & -0.26 & 8.83 & 0.803 \\
\hline${ }^{\mathrm{a}}$ EROS & $\mathrm{kg} \mathrm{ha}^{-1} \mathrm{yr}^{-1}$ & $\dagger$ & 0.20 & 0.27 & -1.78 & 13.34 & 0.098 \\
\hline${ }^{\mathrm{h}} \mathrm{TP} \_$export & $\mathrm{kg} \mathrm{d}^{-1}$ & & 297.99 & 219.14 & 2.18 & 21.46 & $0.040^{*}$ \\
\hline
\end{tabular}


Table 3. (Continued)

\begin{tabular}{|c|c|c|c|c|c|c|}
\hline \multirow[b]{2}{*}{ Parameter } & \multirow[b]{2}{*}{ Units } & \multicolumn{2}{|c|}{ Mean value } & \multicolumn{3}{|c|}{ Statistical results } \\
\hline & & $\begin{array}{l}\text { Burreed/lake } \\
\text { sedge }\end{array}$ & Poor fen & $\mathrm{t}$ & df & $\mathrm{p}$ \\
\hline${ }^{\mathrm{h}} \mathrm{TN}$ _export & $\mathrm{kg} \mathrm{d}^{-1}$ & 5696.44 & 4333.15 & 2.12 & 18.03 & $0.049^{*}$ \\
\hline eDEV_100 & areal fraction & 0.11 & 0.08 & 1.11 & 15.99 & 0.282 \\
\hline eDEV_500 & areal fraction & 0.11 & 0.06 & 1.65 & 22.98 & 0.112 \\
\hline${ }^{\mathrm{e} D E V} \_1000$ & areal fraction & 0.10 & 0.05 & 1.80 & 21.99 & 0.085 \\
\hline${ }^{e}$ DEV_5000 & areal fraction & 0.10 & 0.03 & 3.53 & 17.53 & $0.002^{* *}$ \\
\hline${ }^{\mathrm{a}} \mathrm{FOR} \_100$ & areal fraction & 0.36 & 0.14 & 2.94 & 22.91 & $0.007^{* *}$ \\
\hline${ }^{\mathrm{a}} \mathrm{FOR} \_500$ & areal fraction & 0.36 & 0.21 & 1.71 & 21.67 & 0.102 \\
\hline 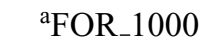 & areal fraction & 0.37 & 0.28 & 1.13 & 21.77 & 0.271 \\
\hline aFOR_5000 & areal fraction & 0.41 & 0.41 & -0.08 & 13.86 & 0.939 \\
\hline
\end{tabular}

${ }^{a}$ Johnston et al., 2009b, ${ }^{b}$ Morrice et al., 2008, ${ }^{\mathrm{c}}$ Reavie et al., 2006, ${ }^{\mathrm{d}}$ Johnston et al., 2008, ${ }^{\mathrm{B}}$ Brazner et al., $2007 \mathrm{~b},{ }^{\mathrm{f}}$ Danz et al., 2007, ${ }^{\mathrm{g}}$ Danz et al., 2005, ${ }^{\mathrm{h}}$ Smith et al., 1997.

widely in the degree of human-related stress; generally, levels of stress decrease from south to north but with considerable variation, especially along the southern shore due to local agricultural activity and the presence of several population and industrial centers.

With its east-west orientation, the U.S. Lake Superior coast is less subject to gradients of latitude and corresponding climatic and biogeographic factors that have had a significant influence on interlake variation in wetland quality compared with other Great Lakes (Niemi et al., 2009). For the four lower Great Lakes, latitude was a significant predictor of wetland condition and was correlated with both natural and anthropogenic stressors, making it often difficult to tease out degradation due to human activity alone (Johnston et al., 2010). Our geographically most distant Lake Superior sites were within one-half degree of latitude of each other, essentially eliminating latitude as a driving variable. Even so, we observed naturally occurring differences associated with hydro-geomorphology and soil characteristics that influenced the flora and fauna present, differences that should be considered when evaluating wetland condition.

In spite of a lack of latitudinal variation, there is human-induced, watershed scale variability across the Lake Superior coast. The establishment of a relationship between watershed disturbance levels and coastal biota using $\delta^{15} \mathrm{~N}$ as an "exposure" indicator links Lake Superior watershed stressors with biology in the coastal receiving waters. Certain coastal habitats showed a strong $\delta^{15} \mathrm{~N}$ response and may be particularly vulnerable to landscape-derived stressors. The ${ }^{15} \mathrm{~N}$ enrichment was particularly high in biota from coastal wetlands, which are typically embedded within the watershed itself and directly receive and process watershed inputs. As landscape flows reach the nearshore waters, in-lake processes can dilute the signal of the adjacent landscape, which would lead to lower $\delta^{15} \mathrm{~N}$ values, as observed. The landscape-nearshore connection has been confirmed by other recent $\delta^{15} \mathrm{~N}$ studies (Peterson et al., 2007). In addition, using continuous high-resolution shoreline surveys $(>500 \mathrm{~km})$ of the nearshore in Lake Superior, Yurista and Kelly (2009) showed that spatial variability in water quality and plankton biomass is significantly correlated with spatial variability in landscape character of the adjacent watersheds along the shore. Thus, given several strong lines of evidence indicating watershedcoastal habitat linkages, we further examined a number of potential biological responses.

Based on the breeding bird communities, the bird assemblage taken as a whole was of a higher quality than expected by the range of human disturbances observed in the landscape, although subtle impacts of disturbances were observed. Wetland complexes in the northern region include breeding bird species more typical of wetlands or wetland edges in forested environments (e.g. American Redstart [Setophaga ruticilla] and white-throated sparrow [Hanowski et al., 2007b]) as well as relatively high numbers of sensitive wetland species. In contrast, we observed that breeding bird communities in the eastern and more southerly regions of the Great 
Lakes were dominated by species associated with agricultural and urban landscapes such as American robin (Turdus migratorius), European starling (a European exotic), mourning dove (Sturnus vulgaris), and brown-headed cowbird (Molothrus ater) (Howe et al., 2007b; Cutright et al., 2006) (Figure 5). This is consistent with data presented in Niemi et al. (2009; Table 3) in which the mean reference condition score based on environmental stress for the U.S. portion of Lake Superior was 6.9 compared with the next highest for Lake Michigan (5.4). However, the mean IEC based on the occurrence of 23 wetland associated bird species was 8.1 compared with the next highest for Lake Michigan of 5.0. The quality of the bird communities themselves are clearly reflected in the quantitative values of the IEC calculations.

Compared to the other Great Lakes, Lake Superior coastal fish communities had more generally intolerant fish and more turbidity intolerant fish. Coastal fish community composition reflected the higher levels of suspended solids associated with human alteration to watersheds. The most disturbed sites on Lake Superior had greater proportions of non-native species and fewer bottom-feeding taxa.

Although Superior is considered the least impacted of the Great Lakes, subtle impacts within this system are detectable using algal indicators of condition. Comparisons of DI TP and DI TSS to individual stressor variables such as agricultural activities revealed significant (albeit relatively low) correlation within Lake Superior. When multiple stressor and water quality variables are considered simultaneously, the diatoms provide a strong indicator of overall environmental quality (Reavie et al., 2006). These sensitive diatom-based indicators will be valuable for paleoecological applications aimed at management because they can be used to reconstruct reference conditions and long-term trends in human impacts. Although not the most sensitive indicators identified in this series of studies, coastal macroinvertebrate communities were nonetheless also able to detect the influence of agriculture and land use across the Lake Superior basin. Select taxonomic, behavioral, and functional feeding groups of wetland invertebrates showed reductions with increasing amounts of agriculture.

Based on their vegetation, Lake Superior's coastal wetlands fell primarily into two groups: northern poor fens and burreed/lake sedge marshes. These two groups were also distinguished by soil properties (i.e. organic vs. mineral soils), differences in the number of growing degree days, and several water chemistry variables. The burreed/lake sedge type usually occurred at the mouths of rivers draining into Lake Superior (St. Louis, Pokegama, Nemadji, Amnicon, Middle, Bois Brule, Flag, Cranberry, Sioux), whereas the northern poor fens were usually not situated on major rivers. Hydrologic modification by transportation corridors and development within five kilometres of the wetland were the anthropogenic stressors that distinguished these two wetland types, but it is not known if that stress caused their vegetation differences or reflected the different physiographic settings of the two groups. Although northern poor fen and burreed/lake sedge plant communities also occurred at three sample sites in northern Lakes Michigan and Huron, the vast majority ( 25 sites) occurred on Lake Superior (Johnston et al., 2009b).

In contrast to previous research on stress gradients across the U.S. Great Lakes coastal area (Danz et al., 2007; Host et al., 2005; Niemi et al., 2007, 2009), the benthic invertebrates, breeding bird, fish, and diatom communities of Lake Superior all exhibited communities distinctive from the other Great Lakes (Figures 3 and 5-7; also Brazner et al., 2007a, 2007b). Even though the stress gradients were relatively wide and similar to many of the other Great Lakes, Lake Superior's physiographic and biogeographic position, as well as its limnology, has a strong influence on its biology.

The analyses presented here for selected biological communities illustrate that each of the sampled taxonomic groups can provide important information on the ecological condition of the U.S. Lake Superior coastal region. Each of the taxa can serve as a "biological indicator" of selected conditions of the coastal region and each can generally inform on potential causes for these conditions (Niemi et al., 2006). To date, our studies suggest that a similar and generalized watershed-coastal connectivity, viewed in terms of the coupling between landscape metrics and stressor delivery and exposure (e.g. our ${ }^{15} \mathrm{~N}$ example), is expressed at a full, region-wide scale across the Great Lakes. However, we find that some biological response indicators for monitoring and assessment are best developed on a lake by lake basis, a situation which arises precisely because there is a biological inherency to each lake. To aid further confidence and use of biological metrics for certain management purposes, we may need to evaluate some finer-scale spatial variability in the coupling 
between landscape conditions and response of biota in coastal receiving systems.

Within Lake Superior individual indicators did not explain more than $55 \%$ of the variation in stressor data. Such a number is typical for large environmental datasets such as this and low explained variation can often be very informative (Gauch, 1982). These results are consistent with Brazner et al. $(2007 \mathrm{a}, \mathrm{b})$ in which considerable unexplained variation exists, likely due to inherent temporal variability in biological data as well as sampling variability. By themselves, several of these indicators are powerful tracers of condition, but it is worth noting that simultaneous application of multiple indicators, as was a major goal of the GLEI initiative, will provide powerful, integrated accounts of coastal condition. Clearly, more research is needed to further calibrate these indicators and more refinement will be necessary to link specific causes with the biological responses observed. Expansion of these data to the Canadian side of the Great Lakes is an obvious priority and necessity. Much of the GIS framework is already established or in progress (Hollenhorst et al., 2007; Host et al., 2011), so the transition to a broader, more comprehensive analysis would be relatively straightforward.

\section{Conclusions}

The information shown here exemplifies the broad effects that many human activities have had and will likely have on the ecological condition of the Lake Superior coastal region in the future. Simultaneous application of multiple indicators will provide a wide array of information about various aspects of Lake Superior's coastal quality. The ecological indicators we have developed, along with the wide breadth of sampling, establish a baseline of conditions for the U.S. Lake Superior coastal region. A standardized sampling framework for these indicators over time can provide a means to detect improvement or further deterioration as well as a means to guide management strategies for future improvements. The integration of these indicators will provide a useful mechanism in the development of a sophisticated monitoring and assessment program of the Lake Superior coastal zone.

\section{Acknowledgements}

J. Hanowski was instrumental in gathering, compiling, and analyzing the breeding bird data. Diatom identification and enumeration results were supported by N. Andresen, G. Sgro, M. Ferguson, and A. Kireta; and diatom taxonomic support was provided by J. Kingston, E. Stoermer, and J. Johansen. D. Breneman, J. Schuldt, J.D. Holland, J.P. Gathman, R. Hell, A. Ly, J. Baillargeon, and J. Wiklund provided assistance with fish and macroinvertebrate data and sampling. M. Aho, A. Boers, K. Bailey Boomer, M. Bourdaghs, K. Cappillino, R. Clark, S. Cronk, A. Freeman, C. Frieswyk, D. James, C. Johnson, L. Ladwig, A. Marsh, M. Tittler, L. Vaccaro, and C. Williams collected vegetation field data. We thank D. McKenney and P. Papadopol of the Great Lakes Forestry Centre for providing the GDD data. Water quality sampling and analysis were supported by J. Henneck, E. Ruzycki, J. Reed, and J. Ameel. R. Regal provided statistical advice. Although this research has been funded wholly or in part by the U.S. EPA through cooperative agreement EPA/R82867501 to the Great Lakes Environmental Indicators project, and through grant EPA/R-82877701 to L. Johnson, it has not been subjected to the agency's required peer and policy review and therefore does not necessarily reflect the views of the agency and no official endorsement should be inferred. This is contribution number 521 from the Center for Water and the Environment, Natural Resources Research Institute, University of Minnesota Duluth.

\section{References}

Ameel, J., Ruzycki, E., Owen, C.J., Axler, R., 1998. Analytical chemistry and quality assurance procedures for natural water, wastewater, and sediment samples (revised 2003). NRRI/TR98/28. Natural Resources Research Institute, University of Minnesota Duluth.

APHA (American Public Health Association), 2000. Standard methods for the examination of water and wastewater, 21st Ed. American Public Health Association, Washington DC.

Barbour, M.T., Gerritsen, J., Snyder, B.D., Stribling, J.B., 1999. Rapid bioassessment protocols for use in streams and wadeable rivers: Periphyton benthic macroinvertebrates and fish (2nd edition). EPA 841-B-99-002. U.S. Environmental Protection Agency; Office of Water; Washington, DC.

Battarbee, R.W., Jones, V.J., Flower, R.J., Cameron, N.G., Bennion, H., Carvalho, L., Juggins, S., 2001. Diatoms. In: J.P. Smol, H.J.B. Birks, W.M. Last (Eds.), Tracking Environmental Change Using Lake Sediments Volume. 3: Terrestrial, Algal, and Siliceous Indicators, pp. 155-202. Kluwer, Dordrecht.

Bernthal, T.W., 2003. Development of a floristic quality assessment methodology for Wisconsin. Final report to U.S. Environmental Protection Agency, Region V. PUB-SS-986 2003. Wisconsin Department of Natural Resources, Madison. 
Bertram, P., Stadler-Salt, N., 1998. Selection of indicators for the Great Lakes basin ecosystem health, Version 3. 1998 State of the Lakes Ecosystem Conference, U.S. Environmental Protection Agency, Great Lakes National Program Office, Chicago, Illinois.

Bertram, P., Stadler-Salt, N., Horvatin, P., Shear, H., 2003. Binational assessment of the Great Lakes SOLEC partnerships. Environ. Monitor. Assess. 81, 27-33.

Bourdaghs, M., Johnston, C.A., Regal, R.R., 2006. Properties and performance of the floristic quality index in Great Lakes coastal wetlands. Wetlands 26, 718-735.

Brady, V.J., Ciborowski, J.J.H., Johnson, L.B., Danz, N.P., Holland, J.D., Breneman, D.H., Gathman, J.P., 2007. Optimizing fishing time: One vs. two-night fyke net sets in Great Lakes coastal systems. J. Great Lakes Res. 33, 236245.

Bray, J.R., Curtis, J.T., 1957. An ordination of the upland forest communities in southern Wisconsin. Ecol. Monogr. 27, 325-349.

Brazner, J.C., Danz, N.P., Niemi, G.J., Regal, R.R., Trebitz, A.S., Howe, R.W., Hanowski, J.M., Johnson, L.B., Ciborowski, J.J.H., Johnston, C.A., Reavie, E.D., Brady, V.J., Sgro, G.V., 2007a. Evaluation of geographic, geomorphic, and human influences on Great Lakes wetland indicators: a multiassemblage approach. Ecol. Indic. 7, 610-635.

Brazner, J.C., Danz, N.P., Niemi, G.J., Regal, R.R., Hollenhorst, T., Host, G.E., Brown, T., Trebitz, A.S., Howe, R.W., Hanowski, J.M., Johnson, L.B., Ciborowski, J.J.H, Johnston, C.A., Reavie, E.D., Sgro, G.V., 2007b. Responsiveness of Great Lakes wetland indicators to human disturbances at multiple spatial scales: a multi-assemblage assessment. J. Great Lakes Res. 33, 42-66.

Burton, T.M., Brazner, J.C., Ciborowski, J.J.H., Grabas, G.P., Hummer, J., Schneider, J., Uzarski, D.G., 2008. Great Lakes coastal wetland monitoring plan. Final report to U.S. EPA Great Lakes National Program Office.

Clarke, K.R., Gorley, R.N., 2006. PRIMER v6: User Manual/Tutorial. PRIMER-E Ltd., Plymouth, United Kingdom.

Cutright, N., Harriman, B., Howe, R., 2006. The Atlas of Wisconsin Breeding Birds. Wisconsin Society for Ornithology, Milwaukee, WI.

Danz, N.P., Regal, R.R., Niemi, G.J., Brady, V.J., Hollenhorst, T.P., Johnson, L.B., Host, G.E., Hanowski, J.M., Johnston, C.A., Brown, T.N., Kingston, J.C., Kelly, J.R., 2005. Environmentally stratified sampling design for the development of Great Lakes environmental indicators. Environ. Monit. Assess. 102, 41-65.

Danz, N.P., Niemi, G.J., Regal, R.R., Hollenhorst, T.P., Johnson, L.B., Hanowski, J.M., Axler, R.P., Ciborowski, J.J.H., Hrabik, T., Brady, V.J., Kelly, J.R., Morrice, J.A., Brazner, J.C., Howe, R.W., Johnston, C.A., Host, G.E., 2007. Integrated gradients of anthropogenic stress in the U.S. Great Lakes basin. Environ. Manage. 39, 631-647.

Dobiesz, N.E., Hecky, R.E., Johnson, T.B., Sarvala, J., Dettmers, J.M., Lehtiniemi, M., Rudstam, L.G., Madenjian, C.P., Witte, F., 2010. Metrics of ecosystem status for large aquatic systems - a global comparison. J. Great Lakes Res. 36, 123-138.

Environment Canada and U.S. Environmental Protection Agency, 2005. State of the Great Lakes 2005. 2006 Nov.
1-3. EPA 905-R-06-001, Governments of Canada and the U.S. Burlington, ON; Chicago, IL.

Epstein, E.J., Judziewicz, E.J., Smith, W.A., 1997. Wisconsin's Lake Superior coastal wetlands evaluation. PUB ER-095 99. Wisconsin's Natural Heritage Inventory Program, Department of Natural Resources, Madison, WI.

Gauch, H.G., 1982. Multivariate Analysis in Community Structure. Cambridge University Press, Cambridge.

Hanowski, J.M., Danz, N.P., Howe, R.W., Regal, R.R., Niemi, G.J., 2007a. Considerations for monitoring breeding birds in Great Lakes coastal wetlands. J. Great Lakes Res. 33, 245-252.

Hanowski, J.M., Danz, N.P., Howe, R.W., Niemi, G.J., Regal, R.R., 2007b. Consideration of geography and wetland geomorphic type in the development of Great Lakes coastal wetland bird indicators. Ecohealth 4, 194-205.

Herman, K.D., Masters, L.A., Penskar, M.P., Reznicek, A.A., Wilhelm, G.S., Brodovich, W.W., Gardiner, K.P., 2001. Floristic quality assessment with wetland categories and examples of computer applications for the state of Michigan, 2nd edition. Michigan Department of Natural Resources, Lansing.

Hilborn, R., Mangel, M., 1997. The ecological detective: confronting models with data. Princeton University Press, New Jersey.

Hilsenhoff, W.L., 1987. An improved biotic index of organic stream pollution. Great Lakes Entomol. 20, 31-39.

Hollenhorst, T.P., Brown, T.N., Johnson, L.B., Ciborowski, J.J.H., Host, G.E., 2007. Methods for generating multi-scale watershed delineations for indicator development in Great Lake coastal ecosystems. J. Great Lakes Res. 33, 13-26.

Host, G.E., Schuldt, J., Ciborowski, J.J., Johnson, L.B., Hollenhorst, T.P., Richards, C., 2005. Use of GIS and remotelysensed data for a priori identification of reference areas for Great Lakes coastal ecosystems. Int. J. Remote Sens. 26, 5325-5342.

Host, G.E., Brown, T.N, Hollenhorst, T.P., Johnson, L.B., and Ciborowski, J.J.H., 2011. High-resolution assessment and visualization of environmental stressors in the Lake Superior basin. Aquatic Ecosystem Health and Management Society 14(4), 376-385.

Howe, R.W., Regal, R.R., Niemi, G.J., Danz, N.P., Hanowski, J.M., 2007a. A probability-based indicator of ecological condition. Ecol. Indic. 7, 793-806.

Howe, R.W., Regal, R.R., Hanowski, J.M., Niemi, G.J., Danz, N.P., Smith, C.R., 2007b. An index of biotic condition based on bird assemblages in Great Lakes coastal wetlands. J. Great Lakes Res. 33, 93-105.

Johnston, C.A., Bedford, B.L., Bourdaghs, M., Brown, T., Frieswyk, C.B., Tulbure, M., Vaccaro, L., Zedler, J.B., 2007. Plant species indicators of physical environment in Great Lakes coastal marshes. J. Great Lakes Res. 33, 106-124.

Johnston, C.A., Ghioca, D., Tulbure, M.G., Bedford, B.L., Bourdaghs, M., Frieswyk, C.B., Vaccaro, L., Zedler, J.B., 2008. Partitioning vegetation response to anthropogenic stress to develop multi-taxa wetland indicators. Ecol. Appl. 18, 983-1001.

Johnston, C.A., Brown, T.N., Hollenhorst, T.P., Wolter, P.T., Danz, N.P., Niemi, G.J., 2009a. GIS in support of ecological 
indicator development. In: Manual of Geographic Information Systems, pp. 1095-1113. American Society for Photogrammetry and Remote Sensing, Bethesda, MD.

Johnston, C.A., Zedler, J.B., Tulbure, M.G., Frieswyk, C.B., Bedford, B.L., Vaccaro, L., 2009b. A unifying approach for evaluating the condition of wetland plant communities and identifying related stressors. Ecol. Appl. 19, 1739-1757.

Johnston, C.A., Zedler, J.B., Tulbure, M.G., 2010. Latitudinal gradient of floristic condition among Great Lakes coastal wetlands. J. Great Lakes Res. 36, 772-779.

Keough, J.R., Thompson, T., Guntenspergen, G.R., Wilcox, D., 1999. Hydrogeomorphic factors and ecosystem responses in coastal wetlands of the Great Lakes. Wetlands 19, 821834.

Kireta, A.R., Reavie, E.D., Axler, R.P., Sgro, G.V., Kingston, J.C., Brown, T.N., Danz, N.P., Hollenhorst, T.P., 2007. Coastal geomorphic variability in the Laurentian Great Lakes: implications for a diatom-based monitoring tool. J. Great Lakes Res. 33, 136-153.

Lawson, R., 2004. Coordinating coastal wetlands monitoring in the North American Great Lakes. Aquat. Ecosys. Health Manage. 7, 215-221.

Mackey, S.D., Goforth, R.R., 2005. Special issue on Great Lakes nearshore and coastal habitats. J. Great Lakes Res. 31, 1-5.

McClelland, J.W., Valiela, I., 1998. Linking nitrogen in estuarine producers to land-derived sources. Limnol. Oceanogr. 43, 577-583.

Morrice, J.A., Danz, N.P., Regal, R.R., Kelly, J.R., Niemi, G.J., Reavie, E.D., Hollenhorst, T.P., Axler, R.P., Trebitz, A.S., Cotter, A.M., Peterson, G.S., 2008. Human influences on water quality in Great Lakes coastal wetlands. Environ. Manage. 41, 347-357.

Niemi, G.J., McDonald, M.E., 2004. Application of ecological indicators. Annu. Rev. Ecol. Evol. Syst. 35, 89111.

Niemi, G., Wardrop, D., Brooks, R., Anderson, S., Brady, V., Paerl, H., Rakocinski, C., Brouwer, M., Levinson, B., McDonald, M., 2004. Rationale for a new generation of ecological indicators for coastal waters. Environ. Health Persp. 112, 979-986.

Niemi, G.J., Axler, R.P., Brady, V.J., Brazner, J., Brown, T.N., Ciborowski, J.H., Danz, N.P., Hanowski, J.M., Hollenhorst, T.P., Howe, R., Johnson, L.B., Johnston, C.A., Reavie, E.D., Simcik, M., Swackhamer, D., 2006. Environmental indicators of the U.S. Great Lakes coastal region. Report NRRI/TR-2006/11 to the U.S. Environmental Protection Agency STAR Program, ver.1. Agreement R82-8675, Washington DC. Prepared by Great Lakes Environmental Indicators Collaboration, Natural Resources Research Institute, University of Minnesota Duluth, $121 \mathrm{pp}+$ attachments (CD).

Niemi, G.J., Kelly, J.R., Danz, N.P., 2007. Foreword. Environmental indicators for the coastal region of the North American Great Lakes: introduction and prospectus. J. Great Lakes. Res. 33, 1-12.

Niemi, G.J., Brady, V.J., Brown, T.N., Ciborowski, J.J.H., Danz, N.P., Ghioca, D.M., Hanowski, J.M., Hollenhorst, T.P., Howe, R.W., Johnson, L.B., Johnston, C.A., Reavie, E.D. 2009. Development of ecological indicators for the U.S. Great Lakes coastal region - A summary of applications in Lake Huron. Aquatic Ecosys. Health Manage. 12, 77-89.

Peterson, G.S., Sierszen, M.E., Yurista, P.M., Kelly, J.R., 2007. Stable nitrogen isotopes of plankton and benthos reflect a landscape-level influence on Great Lakes coastal ecosystems. J. Great Lakes Res. 33, 27-41.

Reavie, E.D., 2007. A diatom-based water quality index for Great Lakes coastlines. J. Great Lakes. Res. 33, 86-92.

Reavie, E.D., Axler, R.P. Sgro, G.V., Danz, N.P., Kingston, J.C., Kireta, A.R., Brown, T.N., Hollenhorst, T.P., Ferguson, M.J., 2006. Diatom-based weighted-averaging transfer functions for Great Lakes coastal water quality: relationships to watershed characteristics. J. Great Lakes Res. 32, 321347.

Ribic, C.A., Lewis, S.J., Melvin, S., Bart, J., Peterjohn, B., 1999. Proceedings of the marsh bird monitoring workshop. U.S. Fish and Wildlife Service, U.S. Geological Survey.

Schierow, L., Chesters, G., 1988. Evaluation of the Great Lakes nearshore index. Water Res. 22, 269-277.

Seilheimer, T.S., Chow-Fraser, P., 2006. Development and use of the wetland fish index to assess the quality of coastal wetlands in the Laurentian Great Lakes. Can. J. Fish. Aquat. Sci. 63, 354-366.

Smith, R.A., Schwarz, G.E., Alexander, R.B., 1997. Regional interpretation of water-quality monitoring data. Water Resour. Res. 33, 2781-2798.

Steinhart, C.E., Schierow, L., Sonzogni, W.C., 1982. An environmental quality index for the Great Lakes. J. Am. Water Res. Assn. 18, 1025-1031.

Strahler, A.N., 1957. Quantitative analysis of watershed geomorphology. Trans. Am. Geophys. Union 8, 913-920.

Trebitz, A.S., Brazner, J.C., Cotter, A.M., Knuth, M.L., Morrice, J.A., Peterson, G.S., Sierszen, M.E., Thompson, J.A., Kelly, J.R., 2007a. Water quality in Great Lakes coastal wetlands: basin-wide patterns and responses to an anthropogenic disturbance gradient. J. Great Lakes. Res. 33, 67-85.

Trebitz, A.S., Brazner, J.C., Brady, V.J., Axler, R., Tanner, D.K., 2007b. Turbidity tolerances of Great Lakes coastal wetland fishes. N. Am. J. Fish. Manage. 27, 619-633.

U.S. EPA, 1983. Methods for chemical analyses of waters and wastes. U.S. Environmental Protection Agency, Cincinnati, Ohio. EPA/600/4-79/020.

U.S. EPA, 1991. The determination of inorganic anions in water by ion chromatography. U.S. Environmental Protection Agency, Cincinnati, Ohio. Environmental Monitoring Systems Laboratory Method 300.0.

U.S. EPA, 1993. Methods for determination of inorganic substances in environmental samples. U.S. Environmental Protection Agency, Cincinnati, OH. EPA/600/R-93/100.

Welch, B.L., 1947. The generalization of "student's" problem when several different population variances are involved. Biometrika 34 (1-2), 28-35.

Yurista, P.M., Kelly, J.R., 2009. Spatial patterns of water quality and plankton from high-resolution continuous in situ sampling along a 537-kilometres nearshore transect of western Lake Superior, 2004. In: M. Munawar, I.F. Munawar (Eds.), State of Lake Superior, pp. 439-471. Ecovision World Monograph Series, Aquatic Ecosystem Health and Management Society, Burlington, ON. 